\title{
French Family Business and Longevity. Have they been conducting sustainable development policies before it became a fashion?
}

\author{
Nicolas Antheaume* \\ Dominique Barvelivien* \\ Paulette Robic*
}

2012/22

EA 4272

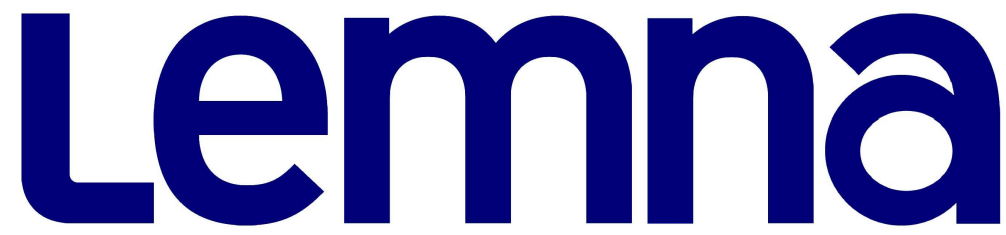


French Family Business and Longevity. Have they been conducting sustainable development policies before it became a fashion?

Nicolas Antheaume ${ }^{\mathrm{ai}}$, Dominique Barbelivien ${ }^{\mathrm{b}}$, Paulette Robic ${ }^{\mathrm{c}}$

${ }^{a, b, c}$ LEMNA - Institute of Economics and Management, University of Nantes, Nantes, France

Corresponding author:

Nicolas Antheaume : nicolas.antheaume@univ-nantes.fr 


\title{
French Family Business and Longevity. Have they been conducting sustainable development policies before it became a fashion?
}

\begin{abstract}
:
Our research started with the following question: have longstanding family businesses been conducting sustainable development policies long before the word became a fashion. After presenting our methodology, we investigate the sustainable development concept and review the family business (FB) literature on longevity in light of the key questions related to sustainable development (SD). We then set out investigate the case of six family businesses which have been in operation for two generations or more. We interviewed 17 different family business owners and members, of six French family businesses, totaling 27 hours of interviews on the longevity of their company. Based on this, and occasionally on written documents, we set out to identify what factors family members associate with the longevity of their company and how these factors stand as regards to the FB and the SD literature.
\end{abstract}

Keywords: family businesses, longevity, long term, sustainable development, history. 


\section{Three generations of family business entrepreneurs: a balance between prolonging}

\section{the past and breaking away from it}

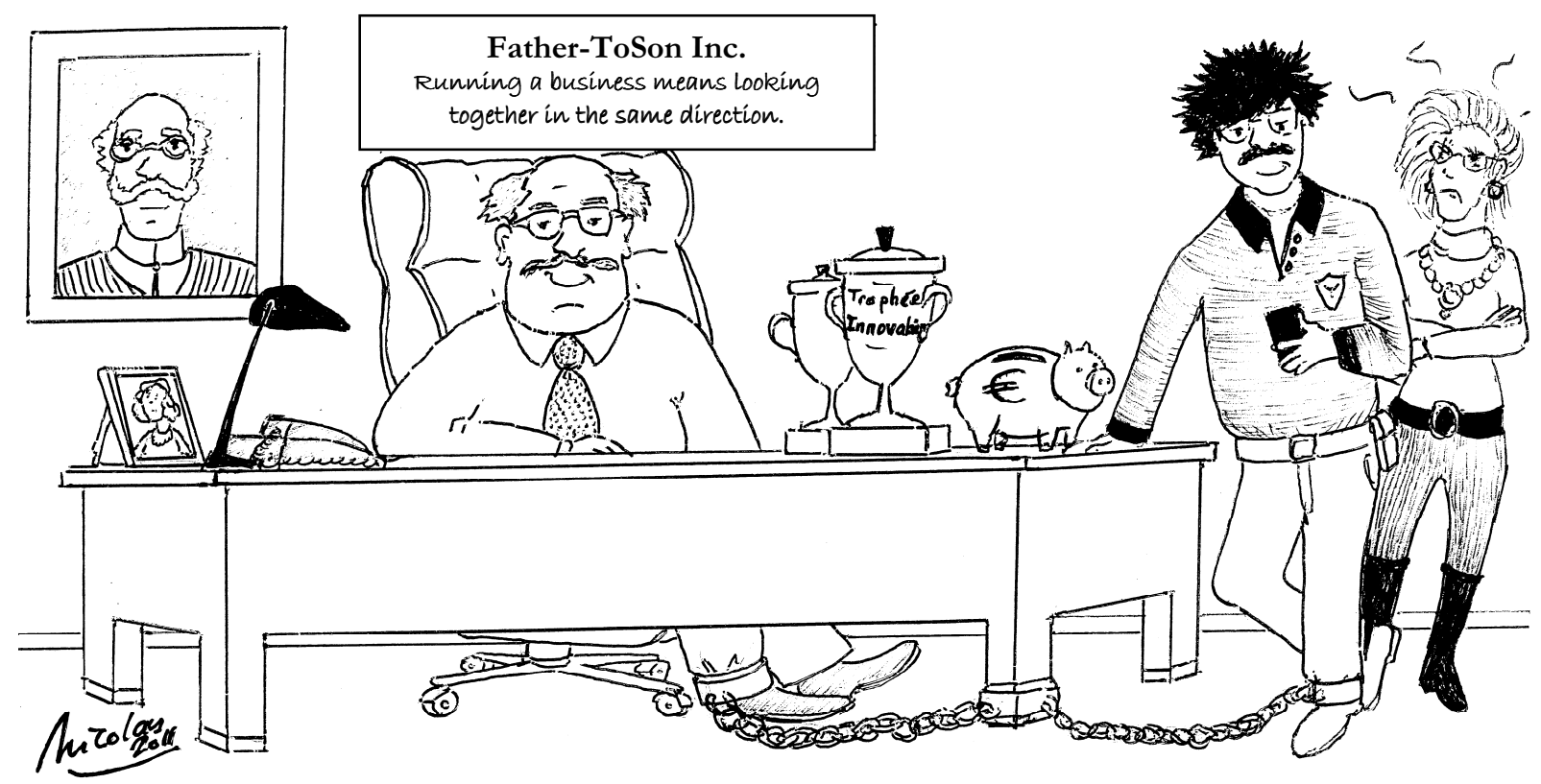

Drawing by Nicolas Antheaume, based on a idea of the authors

\section{Introduction}

In this article we investigate if second, third or even fourth generation family businesses have, in effect, been conducting sustainable development policies long before the word came into existence. Unlike many business academics and professionals we do not equate sustainable development with its applications in organizations in terms of environmental management, sustainability accounting and corporate social responsibility. Thus, do not expect from this article an investigation into whether family businesses have been conducting pollution prevention or used recycled raw materials long before others. Instead, we investigate sustainable development as an interdisciplinary field dedicated to thinking how longevity can be implemented at every level in society so as to ensure the long term survival of humankind. Prior to presenting the outline or our article, let us explain how this idea came to us and present the broad 
lines upon which we conducted our research.

At the time this research project started, one the three authors was co-organizer of a seminar on sustainable development (SD). Very broadly, this seminar was designed as an opportunity for specialists from different disciplines such as biology, law, economics, geography, ... to interact on how SD applied to their discipline and to identify common research topics suited to interdisciplinary work. He had the idea of talking to colleagues who had specialized in the field of family business (FB). He candidly asked them if it would be suitable to assume that FB which had been around for more than two generations might, in fact, have conducted sustainable development policies long before it became a fashion.

This led us to explore and relate the concept of SD to the literature on FB longevity and to interview the owners of $2^{\text {nd }}, 3^{\text {rd }}$ and $4^{\text {th }}$ generation family businesses on the longevity of their company.

In part one we define the methodology we employed in order to collect investigative material through interviews and, occasionally, written documents in six family businesses of the Nantes region, in France. These companies are briefly presented. We also explain how we analyzed the material collected and how we related it to the literature on SD and on FB longevity.

Part two of this article investigates the SD concept, defines it and reviews the FB literature on longevity in light of key SD questions.

Part three is a presentation of our analysis.

In the conclusion of this article, we compare our findings with what we identified in the literature and we suggest leads for future research. 


\section{Part 1. Methodology, presentation of the six companies and of the model}

In this part we start with a presentation of our investigation strategy. We then discuss our data collection methodology and its limits. Finally we present the companies investigated.

\section{Choice of a general investigation method}

Our ambition was to cross:

- a broad research question - have longstanding family businesses been conducting sustainable development policies long before the word became a fashion?

- with emerging data from the fieldwork, collected with a focus on the longevity of family businesses.

We wanted to see if the way they expressed ideas on the history and longevity of their family business would fit, or not with our broad starting assumption. If ever longevity of their business was expressed in terms totally different from what is identified with sustainable development, in that case, we were also curious to discover what they would come up with. We then confronted our results with the literature on FB longevity and with the one on SD.

\section{Choice of data collection: interviews and archives}

To start our investigation we could not build upon a strong base of experience and qualitative studies from which to conceive a questionnaire and develop a statistical analysis. This is why we chose to seek interviews with family business owners. In a 
later section we will elaborate on the design of the interviews and on the status of the data collected.

Our aim of gaining access to archives as a further source of information was only very partially fulfilled because we were confronted with two obstacles: secrecy and the loss of archives.

\section{Secrecy "Pour vivre heureux, vivons cachés"}

All companies which are registered and incorporated in France have to publish at least yearly financial statements, a copy of which must be deposited at the local court of justice. These statements are put on line and various providers propose access to this information ranging from free, basic, simplified statements, to extensive, payable, financial statements with analysis, scores and comparisons with other companies. Companies which do not abide with the obligation of depositing financial statements pay a fine but existing texts do not provide the legislator with powers which would force these companies to publish these statements.

Many business owners in France would rather pay the fine. This is the case with four of the six family businesses we investigated. One the companies in our panel even pushes control of what it makes public so far that journalists have to be accredited in order to obtain a login and a password which will give them access to the online press room on their website. We did manage to get access to key financial data and are currently negotiating access to strategic documents in one of the companies but still need to devise a way of conducting our investigations which will be both academically acceptable and respectful of the secrecy requested by our contacts. Our first line of investigation is to start with the oldest archives and investigate documents which are at least ten or twenty years old. But then, this poses another problem. 
Loss of archives "Poussière tu étais, poussière tu redeviendras"

In at least four of the six companies we investigated, archives were regularly thrown away. And whenever the company expanded, moved into new offices, a number of documents were irremediably lost in the move, or thrown away. The owners did keep a few documents. Mostly, it seems, they are documents which they can exhibit today so as to show how nobody believed in their vision twenty of thirty years ago, and how right they were in sticking to their vision. For example, in a company such as Bon Manger the founders kept letters of banks which had refused to lend them money and provided explanations which today seem ridiculous in view of what the company has become. Another example, still with Bon Manger, is a letter by the Chartered Accountant of the company, dating back to the time when the company chose to automate some of its production processes, and disagreeing with how the founders had calculated the costs and benefits of this investment. Today such a letter is brandished in view of showing that the expert was wrong and that the founders, who had no accounting knowledge, had the right vision. It is difficult to establish today if these "selected archives" reflect a true story of what happened or whether other documents, which do not exist anymore, would provide a more contrasted view of what actually happened. However, even if there is a selective process, one cannot say that it is (always) a conscious one. Archives get thrown away, simply by ignorance of how valuable they become, and because of a lack of adequate storage. Figure 1 is a good illustration of what happened in some of the companies we investigated. It was extracted from one the e-mails we received and translated into English. 
Figure 1. How archives are lost

Hello,

During the month of January, our young methods engineer probably believed he needed more space to store his files. He threw away our handwritten ledgers, the 1954 Japy typewriter of Marie Antoinette (retired accountant) and a score of other old things, leaving a preposterous dustless space on the shelf. My old Jean-Paul, who will retire in two years time, anxiously anticipating the arrival of the dustbin men, managed to salvage his favourite things and to avoid them from being sent to the landfill; but for how many years?

Business being rather tough, with looming under-activity, we have decided to keep part of our team busy in April with transferring cinderblocks in our yard. The plan is to build a storage place for our archives. Hmm ... for how many years?

We are aware that this lack of archives is a limitation. To compensate for this, for each business investigated we tried to seek every opportunity which was presented to us to diversify our interviewees. Furthermore we have not given up all hopes of getting access to some archives in the long run and of finding a good compromise between a desire for secrecy and the imperatives of academic research.

\section{A sample selection methodology based on opportunity}

To meet family business owners we had no database, or address book, from which to operate a sample selection. We thus based our work on what Girin (1989) defined as "methodical opportunism". To start with we defined what a family business is in line with existing studies on FB (Robic 2009), and in accordance with Daumas (2006): «a business is a family one when the family owns enough stock in order for it to control the business's strategic decisions, to chose the top managers, to organize its transmission and to impose its values on the running the of the business ».

Then, with our objectives in mind, we inventoried our personal contacts (former students, business owners we had met, ...) and screened them for compatibility with these objectives. We defined the following criteria to decide whether a contact was 
suitable or not. First, we were looking for owners whose family business had existed for at least two generations or more. Second, within our time and budget limits, we wanted to have access to a diverse sample of family businesses, in terms of size and sector of activity. For example this led us to decide not to expand our sample when a new business we could investigate was similar in terms of size, age, sector to one we already had in our sample. Third, we also wanted to have access to as many different people as possible within a given family business. For example, this helped us decide that an opportunity for an interview in a new business was less of a priority than an interview with a new person in one the businesses already in our sample.

Two initial contacts turned out to be suitable and this is how we conducted our first two interviews. We were betting on the fact that our research would arouse enough interest. This is what happened. The first persons we met led us to suggestions for more contacts, and at some stages some of the people we met did organize appointments on our behalf with people we would not otherwise have had the opportunity to contact on our own. We decided to accept opportunities based on how they fit or not with our three initial criteria. At this stage, we met 17 different persons, from 6 different family businesses which have been around for at least two generations and sometimes for much more. Our interviews total 27 hours which were recorded and fully transcripted.

Based on Miles and Huberman (2003), this selection process can be qualified as part opportunistic, part snowball or chain approach. Although we had no other choice at this stage, we are aware that our process induces a number of biases. Using intermediaries to identify contacts, as mentioned by Blanchet and Gotman (2005), restricts the freedom of the interviewee. Another request is added to the one formulated by the researcher. It may be a friendly, social or institutional one by a third party which superposes itself and blurs the original research request. This may have an impact on 
how the interviewee responds and adjusts himself to the non-research part of the request placed on his shoulders. We are also aware that, in interviews, the respondents may try to project a publicly acceptable image of themselves and that some topics will be difficult to discuss unless there is a bond of trust between the interviewer and interviewee. We are aware that because of this, some subjects of importance to longevity may never come up in the interviews and we have no way of knowing which ones.

Table 1 presents the six family businesses investigated (their names have been changed in order to preserve anonymity) and table 2 summarizes important information about how and with whom our interviews were conducted (names were also changed). Four of the six family businesses in our panel are ranked among the top 500 professional fortunes in France (Le Nouvel Observateur, 2009, 2010). One of them is listed on the French stock market. Three of them have been around for more than three generations. Four out of six are directly managed by a family member who holds a position of chief executive officer. All of them are based in the west of France, in Vendée, a part of France renowned for its industrial network of family entrepreneurs. In four of them the majority of shares is owned by the members of one family. In two of them, two families, affiliated with the original founder, hold a majority of shares. The sectors are very diverse. We are aware that these six companies are very diverse but this was our intention. Once again, it is important to state that we did not have the means to deal with more than a small sample of businesses. We wanted this sample to be as diverse as possible so as to reflect the fact that long standing family businesses are of very diverse types. We did not seek statistical representativity of all types, which is incompatible with our qualitative approach, but we wanted as many different types as possible to be represented. 
Table 1. Presentation of the six family businesses investigated.

\begin{tabular}{|c|c|c|c|c|c|c|}
\hline Name of company & Build o'shell & Bulldoze & Carioll & Bon Manger & Furnishwell & Vandamat \\
\hline Sector of activity & Construction. & Public works. & Leisure vehicules. & Agrifood. & Furniture. & $\begin{array}{l}\text { Manuacturing and } \\
\text { distribution of } \\
\text { building materials. }\end{array}$ \\
\hline Quick history & $\begin{array}{l}\text { First origins in } \\
\text { 1889. Creation of a } \\
\text { limited liability } \\
\text { company in } 1935 . \\
\text { Masonry to start } \\
\text { with and then } \\
\text { structural work and } \\
\text { prefabrication } \\
\text { methods. Five } \\
\text { generations. }\end{array}$ & $\begin{array}{l}\text { The company was } \\
\text { set up in } 1897 \text { by } \\
\text { Mr. Constant } \\
\text { Bulldoze. Started } \\
\text { with earthworks and } \\
\text { then public works. } \\
\text { Is moving into the } \\
\text { management of } \\
\text { landfills. Projects } \\
\text { for ecological } \\
\text { industrial zones. }\end{array}$ & $\begin{array}{l}\text { First origins in } \\
1932 . \text { Woodworker. } \\
1962 \text { : production of } \\
\text { vehicles. } 1972: \\
\text { production of a new } \\
\text { type of vehicle. } \\
1990 \text { et } 2000 \\
\text { takeover of } \\
\text { competitors in } \\
\text { France and } \\
\text { Germany. }\end{array}$ & $\begin{array}{l}\text { The company } \\
\text { started off as a } \\
\text { butcher's shop in } \\
\text { 1960. It expanded as } \\
\text { a large scale } \\
\text { producer in } 1973, \\
\text { selling to other } \\
\text { butchers and to } \\
\text { supermarkets. In } \\
\text { 1978, it began } \\
\text { diversification into } \\
\text { readymade foods } \\
\text { (pizzas, pancake, } \\
\text { Asian dishes, pasta } \\
\text {...). }\end{array}$ & $\begin{array}{l}\text { The company } \\
\text { started off in the } \\
1958 \text { 's as a small } \\
\text { furniture company } \\
\text { specializing in } \\
\text { children's } \\
\text { bedrooms. After } \\
\text { being on the brink } \\
\text { of bankruptcy in the } \\
\text { mid } 80 \text { 's, the } \\
\text { company was taken } \\
\text { over by an } \\
\text { investment fund. In } \\
\text { 1999, a wave of } \\
\text { social unrest leads } \\
\text { the brother in law of } \\
\text { the founder to buy } \\
\text { back the company } \\
\text { through an LBO. }\end{array}$ & $\begin{array}{l}\text { The company was } \\
\text { set up in } 1907 \text { and } \\
\text { quickly diversified } \\
\text { into manufacturing } \\
\text { building materials } \\
\text { (1923) and the } \\
\text { trading of such } \\
\text { materials (1945). } \\
\text { Part of its equity } \\
\text { was listed on the } \\
\text { French stock market } \\
\text { in } 1990 \text {. }\end{array}$ \\
\hline $\begin{array}{l}\text { Key figures } 2009 \\
\text { (real figures may } \\
\text { differ a little bit, but } \\
\text { order of magnitude } \\
\text { is respected). }\end{array}$ & $\begin{array}{l}\text { Sales } 10 \mathrm{M€} \\
76 \text { employees. }\end{array}$ & $\begin{array}{l}\text { Sales } 300 \mathrm{M} € \\
1600 \text { employees, } \\
\text { out of which } 90 \% \text { in } \\
\text { the west of France. } \\
450^{\text {th }} \text { professional } \\
\text { fortune in France. }\end{array}$ & $\begin{array}{l}\text { Sales } 150 \mathrm{M} € . \\
720 \text { employees. } \\
365^{\text {th }} \text { professional } \\
\text { fortune in France. }\end{array}$ & $\begin{array}{l}\text { Sales } 450 \text { M€. } \\
2000 \text { employees. } \\
260^{\text {th }} \text { professional } \\
\text { fortune in France. }\end{array}$ & $\begin{array}{l}\text { Sales } 160 \mathrm{M} € \\
1000 \text { employees }\end{array}$ & $\begin{array}{l}\text { Sales. } 600 \mathrm{M€} \text {. } \\
\text { Over } 3000 \\
\text { employees. } \\
330^{\text {th }} \text { professional } \\
\text { fortune in France. }\end{array}$ \\
\hline Situation of family & $\begin{array}{l}\text { Two cousins who } \\
\text { are equal partners. } \\
\text { One is chief } \\
\text { executive officer, } \\
\text { one is technical } \\
\text { executive officer. }\end{array}$ & $\begin{array}{l}\text { Two families own } \\
100 \% \text { of the } \\
\text { business. Two } \\
\text { families share the } \\
\text { key positions. CEO, } \\
\text { chairman of the } \\
\text { executive board, } \\
\text { chairman of the } \\
\text { supervisory board. }\end{array}$ & $\begin{array}{l}\text { The family owns } \\
100 \% \text { of the } \\
\text { business. } \\
\text { The main } \\
\text { shareholder is non } \\
\text { executive officer } \\
\text { and chairman of the } \\
\text { board. } \\
\text { An executive } \\
\text { managing director } \\
\text { in charge of running } \\
\text { operations and } \\
\text { general } \\
\text { administration. He } \\
\text { is not a member of } \\
\text { the family. }\end{array}$ & $\begin{array}{l}\text { The family owns } \\
100 \% \text { of the shares. } \\
\text { The founders, } \\
\text { husband and wife, } \\
\text { are still major } \\
\text { shareholders and } \\
\text { have given } \\
\text { executive powers to } \\
\text { their three daughters } \\
\text { who define theme } \\
\text { selves as co- } \\
\text { chairwomen. }\end{array}$ & $\begin{array}{l}\text { The brother in law } \\
\text { of the founder and } \\
\text { his family own } 75 \% \\
\text { of the shares. } \\
\text { The brother in law } \\
\text { of the founder is } \\
\text { chief executive } \\
\text { officer. His elder } \\
\text { son is his closest } \\
\text { advisor and chosen } \\
\text { successor. Another } \\
\text { son is in charge of } \\
\text { engineering } \\
\text { processes, yet } \\
\text { another one is } \\
\text { responsible for } \\
\text { international } \\
\text { development. His } \\
\text { daughter is in } \\
\text { charge of the } \\
\text { development of the } \\
\text { network of } \\
\text { franchisees. }\end{array}$ & $\begin{array}{l}\text { Two families own } \\
\text { nearly } 70 \% \text { of the } \\
\text { business. The rest is } \\
\text { listed on the French } \\
\text { stock market. The } \\
\text { chief executive } \\
\text { officer is not a } \\
\text { member of the } \\
\text { family. }\end{array}$ \\
\hline Geographical span. & $\begin{array}{l}\text { Regional (Vendée, } \\
\text { Nantes, Angers) }\end{array}$ & $\begin{array}{l}\text { The west of France } \\
+ \text { a few national and } \\
\text { international } \\
\text { contracts. }\end{array}$ & Europe. & $\begin{array}{l}\text { Mostly France. } \\
\text { Spain and the UK to } \\
\text { a smaller extent. }\end{array}$ & $\begin{array}{l}\text { International (recent } \\
\text { expansion into } \\
\text { China and India). }\end{array}$ & $\begin{array}{l}\text { International (recent } \\
\text { expansion into } \\
\text { China). }\end{array}$ \\
\hline $\begin{array}{l}\text { Documentary } \\
\text { sources }\end{array}$ & $\begin{array}{l}\text { Simplified financial } \\
\text { statements. } \\
\text { Commercial } \\
\text { documents. } \\
\text { Website. } \\
\text { Internal documents } \\
\text { (organizational } \\
\text { charts). }\end{array}$ & $\begin{array}{l}\text { Commercial } \\
\text { documents. } \\
\text { Website. }\end{array}$ & $\begin{array}{l}\text { Press review. } \\
\text { Commercial } \\
\text { documents. } \\
\text { Website. } \\
\text { Case study carried } \\
\text { out by students. }\end{array}$ & $\begin{array}{l}\text { Press review. } \\
\text { Commercial } \\
\text { documents. } \\
\text { Website. } \\
\text { Case study carried } \\
\text { out by students. }\end{array}$ & $\begin{array}{l}\text { Press review. } \\
\text { Commercial } \\
\text { documents. } \\
\text { Website. }\end{array}$ & $\begin{array}{l}\text { Press review. } \\
\text { Commercial } \\
\text { documents. } \\
\text { Website. } \\
\text { Case study carried } \\
\text { out by students. }\end{array}$ \\
\hline
\end{tabular}


Table 2. Description of the interviews carried out

\begin{tabular}{|c|c|c|c|c|c|c|c|c|c|}
\hline $\begin{array}{l}\text { Name of } \\
\text { company }\end{array}$ & $\begin{array}{l}\text { Company } \\
\text { visit? }\end{array}$ & People met & Family status & Professional status & $\begin{array}{l}\text { Times } \\
\text { met }\end{array}$ & Location & $\begin{array}{l}\text { Feedback } \\
\text { on initial } \\
\text { research } \\
\text { paper }\end{array}$ & $\begin{array}{l}\text { Type of } \\
\text { interview }\end{array}$ & $\begin{array}{l}\text { Total } \\
\text { duration of } \\
\text { interviews }\end{array}$ \\
\hline \multirow[t]{2}{*}{$\begin{array}{l}\text { Carioll } \\
\text { (France) }\end{array}$} & \multirow[t]{2}{*}{$\begin{array}{l}\text { Yes, guided by } \\
\text { Mr Carioll. }\end{array}$} & $\begin{array}{l}\text { Mr Carioll } \\
\text { Born circa } \\
1948 .\end{array}$ & $\begin{array}{l}\text { Direct heir, } 2^{\text {nd }} \\
\text { generation }\end{array}$ & $\begin{array}{l}\text { President of the board, } \\
\text { Non executive officer }\end{array}$ & $\begin{array}{l}\text { Three } \\
\text { times. }\end{array}$ & $\begin{array}{l}\text { Twice at } \\
\text { University. Once at } \\
\text { his office. }\end{array}$ & Yes & $\begin{array}{l}\text { Once with his } \\
\text { wife. } \\
\text { Twice alone. }\end{array}$ & \multirow[t]{2}{*}{$\begin{array}{l}5 \text { hours, Fully } \\
\text { transcripted. }\end{array}$} \\
\hline & & $\begin{array}{l}\text { Mrs Carioll } \\
\text { Born circa } \\
1950\end{array}$ & $\begin{array}{l}\text { Wife of } \mathrm{Mr} \\
\text { Carioll. }\end{array}$ & $\begin{array}{l}\text { Unofficial Public } \\
\text { Relations Officer. Non } \\
\text { paid, member of } \\
\text { strategic committee }\end{array}$ & Once. & At University. & & & \\
\hline \multirow[t]{4}{*}{$\begin{array}{l}\text { Bulldoze } \\
\text { (France) }\end{array}$} & $\begin{array}{l}\text { No. But visit } \\
\text { of family } \\
\text { house. }\end{array}$ & $\begin{array}{l}\text { Mrs R.J. } \\
\text { Bulldoze } \\
\text { Born } 1928\end{array}$ & $\begin{array}{l}\text { Wife of one of } \\
\text { grandsons of } \\
\text { the founder. }\end{array}$ & $\begin{array}{l}\text { Retired. Co-managed } \\
\text { the company with } \\
\text { brother in law, upon } \\
\text { death of her husband, } \\
\text { from } 1971 \text { to } 1979 .\end{array}$ & Once & $\begin{array}{l}\text { In the family } \\
\text { house. Just next to } \\
\text { company } \\
\text { headquarters. }\end{array}$ & No. & Alone. & $\begin{array}{l}1 \text { hour. Fully } \\
\text { transcripted. }\end{array}$ \\
\hline & & $\begin{array}{l}\text { Mr G.A. } \\
\text { Bulldoze } \\
\text { Born } 1953\end{array}$ & $\begin{array}{l}\text { Heir. 4th } \\
\text { Generation. } \\
\text { One of the } \\
\text { great grand } \\
\text { sons of the } \\
\text { founder. }\end{array}$ & $\begin{array}{l}\text { Chief executive } \\
\text { officer and chairman } \\
\text { of the executive board. }\end{array}$ & Twice. & $\begin{array}{l}\text { Once in company } \\
\text { headquarters in his } \\
\text { office. Once at the } \\
\text { chamber of } \\
\text { commerce. }\end{array}$ & Yes. & $\begin{array}{l}\text { Once alone. } \\
\text { Once with a } \\
\text { consultant } \\
\text { (Mrs } \\
\text { Counsellor). }\end{array}$ & $\begin{array}{l}3 \text { hours. Fully } \\
\text { transcripted. }\end{array}$ \\
\hline & & $\begin{array}{l}\text { Mrs S.R. } \\
\text { Bulldoze } \\
\text { Born } 1955\end{array}$ & $\begin{array}{l}\text { Heir 4th } \\
\text { generation. } \\
\text { One of the } \\
\text { grand } \\
\text { daughters of } \\
\text { the founder. }\end{array}$ & $\begin{array}{l}\text { Member of the } \\
\text { supervisory board. }\end{array}$ & Once. & In her house. & No. & Alone. & $\begin{array}{l}3 \text { hours. Fully } \\
\text { transcripted. }\end{array}$ \\
\hline & & $\begin{array}{l}\text { Mrs K. } \\
\text { Counsellor }\end{array}$ & $\begin{array}{l}\text { Not a family } \\
\text { member. }\end{array}$ & Consultant. & Once. & $\begin{array}{l}\text { At the chamber of } \\
\text { commerce. }\end{array}$ & No & $\begin{array}{l}\text { With M. G.A. } \\
\text { Bulldoze. }\end{array}$ & $\begin{array}{l}2 \text { hours. } \\
\text { Fully } \\
\text { transcripted. }\end{array}$ \\
\hline \multirow[t]{3}{*}{$\begin{array}{l}\text { Build o'shell } \\
\text { (France) }\end{array}$} & No. & $\begin{array}{l}\text { Mrs Jeanine. } \\
\text { o'Shell } \\
\text { Born circa } \\
1935\end{array}$ & $\begin{array}{l}\text { Wife of one } \\
\text { the grand sons } \\
\text { of the founder. } \\
\text { Herself a } 2^{\text {nd }} \\
\text { generation heir } \\
\text { of a family } \\
\text { business that } \\
\text { was sold. }\end{array}$ & $\begin{array}{l}\text { Retired. Worked as an } \\
\text { accountant and } \\
\text { "unofficial" Public } \\
\text { Relations Officer. } \\
\text { Until the death of her } \\
\text { husband. }\end{array}$ & Once. & $\begin{array}{l}\text { In the family } \\
\text { house, just next to } \\
\text { company } \\
\text { headquarters. }\end{array}$ & No. & Alone. & $\begin{array}{l}1,25 \text { hours } \\
\text { Fully } \\
\text { transcripted. }\end{array}$ \\
\hline & & $\begin{array}{l}\text { Mr O'Shell } \\
\text { Born } 1969 .\end{array}$ & $\begin{array}{l}\text { Heir. 5th } \\
\text { generation. } 4^{\text {th }} \\
\text { child and only } \\
\text { son. }\end{array}$ & $\begin{array}{l}\text { Chief Executive } \\
\text { Officer and Partner. }\end{array}$ & Twice. & $\begin{array}{l}\text { Once at university. } \\
\text { Once at company } \\
\text { headquarters in his } \\
\text { office. }\end{array}$ & Yes. & Alone. & $\begin{array}{l}4 \text { hours, Fully } \\
\text { transcripted. }\end{array}$ \\
\hline & & $\begin{array}{l}\text { Mrs Mary } \\
\text { O'Shell } \\
\text { Born } 1950\end{array}$ & $\begin{array}{l}\text { Heir. } 5^{\text {th }} \\
\text { generation. } \\
\text { One of the } \\
\text { three } \\
\text { daughters. }\end{array}$ & $\begin{array}{l}\text { Sold her shares } 25 \\
\text { years ago. } \\
\text { Accountant in the } \\
\text { company. }\end{array}$ & Once. & $\begin{array}{l}\text { At company } \\
\text { headquarters. }\end{array}$ & No. & Alone. & $\begin{array}{l}45 \text { minutes } \\
\text { Fully } \\
\text { transcripted) }\end{array}$ \\
\hline \multirow[t]{5}{*}{ Bon Manger } & \multirow[t]{5}{*}{$\begin{array}{l}\text { Yes. Guided } \\
\text { by an } \\
\text { employee. }\end{array}$} & $\begin{array}{l}\text { Mrs Cutts } \\
\text { Born circa } \\
1935 . \\
\end{array}$ & Founder. & Member of the board. & \multirow[t]{5}{*}{ Once. } & \multirow[t]{5}{*}{$\begin{array}{l}\text { At company } \\
\text { headquarters. }\end{array}$} & \multirow[t]{5}{*}{ No. } & \multirow[t]{5}{*}{$\begin{array}{l}\text { The five } \\
\text { protagonists } \\
\text { met us } \\
\text { together. }\end{array}$} & \multirow{5}{*}{$\begin{array}{l}3 \text { hours. Fully } \\
\text { transcripted. } \\
\text { Plus lunch, } \\
\text { non } \\
\text { transcripted. }\end{array}$} \\
\hline & & $\begin{array}{l}\text { Mr Cutts } \\
\text { Born } \\
\text { Born circa } \\
1935 .\end{array}$ & Founder. & Member of the board. & & & & & \\
\hline & & $\begin{array}{l}\text { Mrs Roast } \\
\text { Born circa } \\
1960 .\end{array}$ & $\begin{array}{l}\text { Daughter of } \\
\text { the founders. }\end{array}$ & Co-chairman & & & & & \\
\hline & & $\begin{array}{l}\text { Mrs Archit } \\
\text { Born circa } \\
1965 .\end{array}$ & $\begin{array}{l}\text { Daughter of } \\
\text { the founders. }\end{array}$ & Co-chairman & & & & & \\
\hline & & $\begin{array}{l}\text { Mrs Meet } \\
\text { Born circa } \\
1970 .\end{array}$ & $\begin{array}{l}\text { Daughter of } \\
\text { the founders. }\end{array}$ & Co-chairman & & & & & \\
\hline Vandamat & No. & Mr Joss & $\begin{array}{l}\text { Not a family } \\
\text { member. }\end{array}$ & $\begin{array}{l}\text { Chief Executive } \\
\text { Officer. }\end{array}$ & Once. & $\begin{array}{l}\text { At company } \\
\text { Headquarters. }\end{array}$ & No. & Alone. & $\begin{array}{l}1 \text { hour. } \\
\text { Fully } \\
\text { transcripted. }\end{array}$ \\
\hline Furnishwell & No. & $\begin{array}{l}\text { Mr Wood } \\
\text { Born in } 1958 .\end{array}$ & $\begin{array}{l}\text { Son in law of } \\
\text { the founder. }\end{array}$ & $\begin{array}{l}\text { Main shareholder and } \\
\text { Chief Executive } \\
\text { Officer. }\end{array}$ & Once. & $\begin{array}{l}\text { At company } \\
\text { headquarters. }\end{array}$ & No. & Alone. & $\begin{array}{l}3 \text { hours. Fully } \\
\text { transcripted. }\end{array}$ \\
\hline
\end{tabular}




\section{Design and conduct of the interviews}

Based on the recommendation of Miles and Huberman (2003) we developed an initial framework so as to identify the variables which we wanted to study, and which were related to our question. An initial round of the French literature on FB led us to identify a number of ideas related to longevity which we wanted to investigate. The first one was that if some family businesses had been around for a long time, it was because they had successfully managed to survive important internal and external crises. Thus, we asked our respondents to tell us about past crises the company had lived through. The second idea was that family businesses were able to use and interconnect three interest groups and networks: the family, employees, and external stakeholders. Thus we also questioned our interviewees on their relationship with family members, employees and other stakeholders. We also asked them about the clubs, associations, parties and other organisations to which they belonged and/or devoted time to. More generally speaking we asked them to tell us about the history of their company and of their family. We let them speak as much as possible and only asked questions when our respondent had finished talking about a given subject.

Thus, although we had a broad list of questions in mind, we made every effort to keep interviews as non directive as possible. We presented ourselves as researchers with an interest in studying the longevity of family businesses, but also as academics with a desire to open up our students to the world of family business through examples and case studies used in the class. In no way did we ask direct questions about sustainable development, or about how they view the interaction between the business, the family and society. As mentioned above we asked them speak as openly as possible about their personal history, about crises the company had gone through, about the history of the business, about what had changed and what had remained the same. Based on the 
definition proposed by Minichiello et al. (1990), an unstructured interview is one where the question and answer categories are not predetermined and where the interview takes place more as conversation in which the interaction between interviewer and interviewee brings out information. Gavard-Perret et al. (2008) also added that a non directive interview is one where the research question is not explained directly to the interviewee. The above definitions correspond to what we strived to do.

\section{Interpretative analysis of the data}

Our approach is inductive and interpretative. The validity of our results is obtained through an independent analysis of each author and through the confrontation of these individual analyses. The latter were conducted in a way that is consistent with the guidelines of grounded theory laid out by Glaser and Strauss (2010) and with the recommendations of interview analysis provided by Miles and Huberman (2003).

Each of the co-authors, based on the transcript of the interviews, presented to the others a written report on what explained, according to him, the longevity of each of the businesses studied, and based on what information, contained in the transcripts, he expressed this point of view.

The analysis of the co-authors was then confronted. Converging opinions were identified. The few diverging views (approximately 10\% of all the subjects discussed) were debated until a common understanding was reached. At the end of the discussions, no diverging opinions were left standing.

Each co-author then expressed an opinion, in writing, on which of the businesses studied would have the best chances of being passed on to the next generation, and had to justify his opinion based on information contained in the transcripts. The same process as above was developed. 
Whenever possible, we also drew a comparison with 10 case studies carried out by Master's degree students, on family businesses, some of which had failed to last.

Three of the persons interviewed were met at least a second time, after we had written a preliminary research paper based on the investigation of four businesses, so as to confront our preliminary analyses with their point of view.

This translated into a list of keywords, which we grouped into categories and concepts. Finally, we linked them with outcomes in terms of longevity. In the end we tried to relate our categories to each other, in order to define a model that would explain the longevity of the businesses investigated. Of course, we acknowledge that this is based so far on what business owners and family members accepted to tell us.

\section{Part 2. An investigation into the concept of sustainable development and a review of literature on the longevity of family businesses}

The idea that long lasting family businesses have been conducting sustainable development before it became a fashion may have been a candid assumption to start with. However it was one which gave us the impetus needed to start this research and it requested that we enquire about the SD concept. This is what we do in the first section of this second part. We then move on to the literature on family business longevity.

\section{An investigation into the concept of sustainable development}

The most cited text on sustainable development (SD) is undoubtedly the one written by the United Nations' World Commission on Environment and Development (WCED, 1987). It defines SD as a mode of development which satisfies the needs of present generations but does not hamper the needs of future generations.

In his genealogy of this concept Mebratu (1998) presents SD as the combination of a number of conceptual precursors. Prior to the first Stockholm Conference on 
Environment and Development in 1972, the author identifies such precursors as a number of religious beliefs and traditions, the Malthusian and Riccardian theory of limits as well as the political concept of scale of organizations summarized by Schumacher as "Small is beautiful". The 1972 Stockholm conference on environment and development enabled major advances to be made by suggesting that economic development as it was known at the time would have to be altered. This led to the term "Eco-Development" which appeared for the first time in a UN Environment programme review in 1978. As for the word "Sustainable Development" it was used in 1980 for the first time in the subtitle of a report on conservation elaborated by the International Union for the Conservation of Nature, in close cooperation with the UN Environmental Programme and the WWF.

When one reads the 1987 WCED report, beyond the above definition, one sees two important messages from which this definition stems.

- The current environmental crisis is linked to the interlocking of environmental, social and economic spheres. This is illustrated by figure 2 .

- Failure to solve this environmental crisis is largely attributed to the compartmentalization of institutions respectively in charge of these aspects. This is illustrated by figure 3 .

Figure 2. The interlocking of economic and ecological spheres (WCED, 1987, paragraph 15)

\footnotetext{
These related changes have locked the global economy and global ecology together in new ways. We have in the past been concerned about the impacts of economic growth upon the environment. We are now forced to concern ourselves with the impacts of ecological stress degradation of soils, water regimes, atmosphere, and forests upon our economic prospects. We have in the more recent past been forced to face up to a sharp increase in economic interdependence among nations. We are now forced to accustom ourselves to an accelerating ecological interdependence among nations. Ecology and economy are becoming ever more interwoven locally, regionally, nationally, and globally into a seamless net of causes and effects.
} 
Figure 3. The compartmentalization of institutions (WCED, 1987, paragraph 32)

Yet most of the institutions facing those challenges tend to be independent, fragmented, working to relatively narrow mandates with closed decision processes. Those responsible for managing natural resources and protecting the environment are institutionally separated from those responsible for managing the economy. The real world of interlocked economic and ecological systems will not change; the policies and institutions concerned must.

Furthermore the WCED, insists in its policy directions on the need to:

- develop human resources to build up technical knowledge and capabilities as well as values which individuals cope with rapid economic, social and environmental changes;

- $\quad$ to preserve the potential of natural and agricultural resources by treating them as a capital to be maintained and to develop a system of incentives which help people live off the interests of this capital;

- to develop "low energy" economic models which can function with renewable energy sources. Eco-efficiency is presented as a means to buy enough time to conceive these models.

The above recommendations and others not quoted here, point to the need to build up and preserve human, economic and natural capital, the interests of which present and future generations can use to satisfy their needs.

Mitcham (1995) thus presents SD as an ideal which aims at reconciling two contradictory needs: on one side, the need to think the limits to growth, in line with the founding work of the Club of Rome (Meadows et al., 1972); on the other side, a real need for economic and social development. Hence, SD is preoccupied with managing contradictions, so as to ensure the longevity of humankind. Our concern with SD, for the purpose of this research, is not related to business applications and concepts, such as environmental management, sustainability accounting or corporate social responsibility. 
It lies in the fact that researchers in the field of sustainable development have proposed solutions to manage these contradictions and proposed ideas to ensure the longevity of humankind.

O’Riordan (1991) and Mebratu (1998) show that different interest groups (religious, business, academic and political ones) have proposed their own interpretation of how this articulation of economic, social and ecological spheres should be conducted; based on their own vision of the world and of how far they perceive we are from sustainable development. For radical ecologists, SD will be attained only if we abandon an anthropocentric vision of the world and take into account the needs of other living creatures on earth. For representatives of the business world, sustainable development will be implemented through the concept of eco-efficiency, which combines economic imperatives with environmental stewardship, and enables society as a whole to benefit from longer term perspectives as to the availability of non-renewable resources.

Although we acknowledge that simplifying does not do justice to the richness of the different visions on how to reach a state of $\mathrm{SD}$, we believe they can be roughly equated to two different visions, summed up in figure 4. 
Figure 4: Two different visions of sustainable development (based on WCED (1987), Mebratu (1998) and Passet (1996).
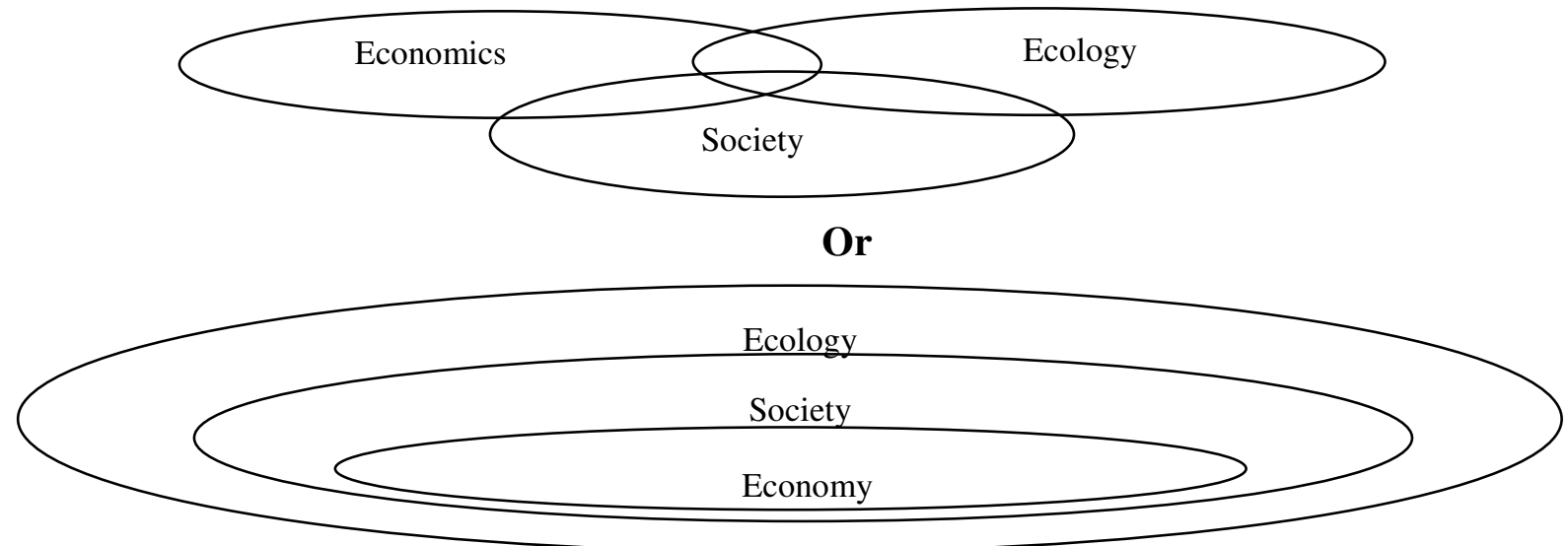

In the first diagram of figure 4 , the three systems, economics, ecology and society are conceived as independent from one another and can be optimized separately from each other. However, only the intersection between the three zones is assumed to correspond to sustainable development. Any activity which takes place out of this intersection zone will create contradictions and imbalances. The second diagram of figure 4 insists on the fact that economic and social spheres cannot be thought independently of their "life support system" which is the ecological sphere. The interactions between the three spheres are managed by processes which do not specifically belong to one sphere.

Although the WCED report on sustainable development (WCED, 1987) has been much decried for proposing a vision of this concept which is two consensual and not operational enough, it contains two powerful recommendation which even today are not fully being put into practice. The first one is that in order to reach a goal of SD no economic problem can be treated independently of its social and ecological consequences. The same recommendations can be formulated for social and ecological problems. The second one is that a long term perspective should be adopted so as to 
take the fate of future generations into account. With due acknowledgment to Professor Collard du Tilleul ${ }^{\text {ii }}$ let us take an example of how these recommendations are still not applied more than 20 years after this report was published. In 2008, three important conferences with consequences on food supply were organised.

- The first conference was on food security (a social aspect of food supply) Rome, June 5, 2008.

- The second conference was organised on the Doha round to settle negotiations on the free movement of agricultural goods (an economic aspect of food supply), Geneva, July 21, 2008.

- The third conference was on global warming (an environmental consequence of how food supply is organised), Poznan, December 2008.

There was no coordination between the three conferences which each dealt with their side of the problem. The results of the first conferences were also not fed into the decision making process of the following ones. Although it is largely a matter of opinion, if we accept the idea that these three conferences failed in reaching an agreement between the participants, this also signals an inability by some decision makers to take long term perspectives into account.

Based on the fact that some long lasting family businesses have been around for longer than existing definition of SD, have their owners been practising the ability to:

- think in a systemic manner - problems are interconnected (family ones, business ones, economic ones, social ones, ...) and cannot be solved separately from one another,

- integrate long term perspectives in their decision making processes.

Let us now turn to the literature on FB longevity and see what it has to say on these two questions. 


\section{Review of literature on family businesses and their longevity}

Part of the literature on family business and longevity has not dealt directly with the two above questions. However it has demonstrated and documented the fact that, for a long time, family businesses have always played a key role in the economy. This has been emphasized by authors such as Allouche and Amann (2000); Kenyon-Rouvinez and Ward (2004). Through his work on the history of major family businesses during the three decades after world war two, Daumas (2006) shows how constantly present family based capitalism is, even though economic theory predicted and encouraged its disappearance to the advantage of managerial capitalism. This is also shown by Colli and Rose $(2003,2007)$ in their study of family businesses. As for Faccio and Lang (2002), they show, in their study of the ultimate ownership of western corporations, based on a sample of 5232 corporations in 13 European countries, that $44,21 \%$ of firms are family controlled. However, transmission to the next generation is not systematic. The French Ministry for the Economy investigated this question in 2009 but no figures were made publicly available.

In the Anglo-Saxon world, many researchers such as Stafford (1999), Olson (2003), Arrègle et al. (2004), Miller and Le Breton-Miller (2005, 2006, 2011) have studied the longevity of family business. However, in France, only a few of them have investigated this question (Mignon, 1998, 2000, 2009 ; Blondel and Dumas, 2008). Let us confront this literature with the SD one, on the questions of systemic and long term thinking.

We identified a set of researchers for which the longevity of family businesses is indeed explained by a systemic approach. As early as 1983, Lansberg proposed the idea that the FB is a complex system which links two intertwined social institutions: the family and the business. Lansberg (1988), Davis and Tagiuri (1989, 1992) adopt a 
visual approach of this systemic vision through a Venn ${ }^{\text {iii }}$ diagram so as provide an overview of how these businesses function (figure 5). This model shows that the Family Business is an outcome of the interactions and connexions between the different elements of this system. It produces key attributes of the family business such as a long history, emotional engagement; a shared symbolic vision of the family business ... These attributes can be, in turn, either strengths or weaknesses for the FB.

Figure 5. The family business system

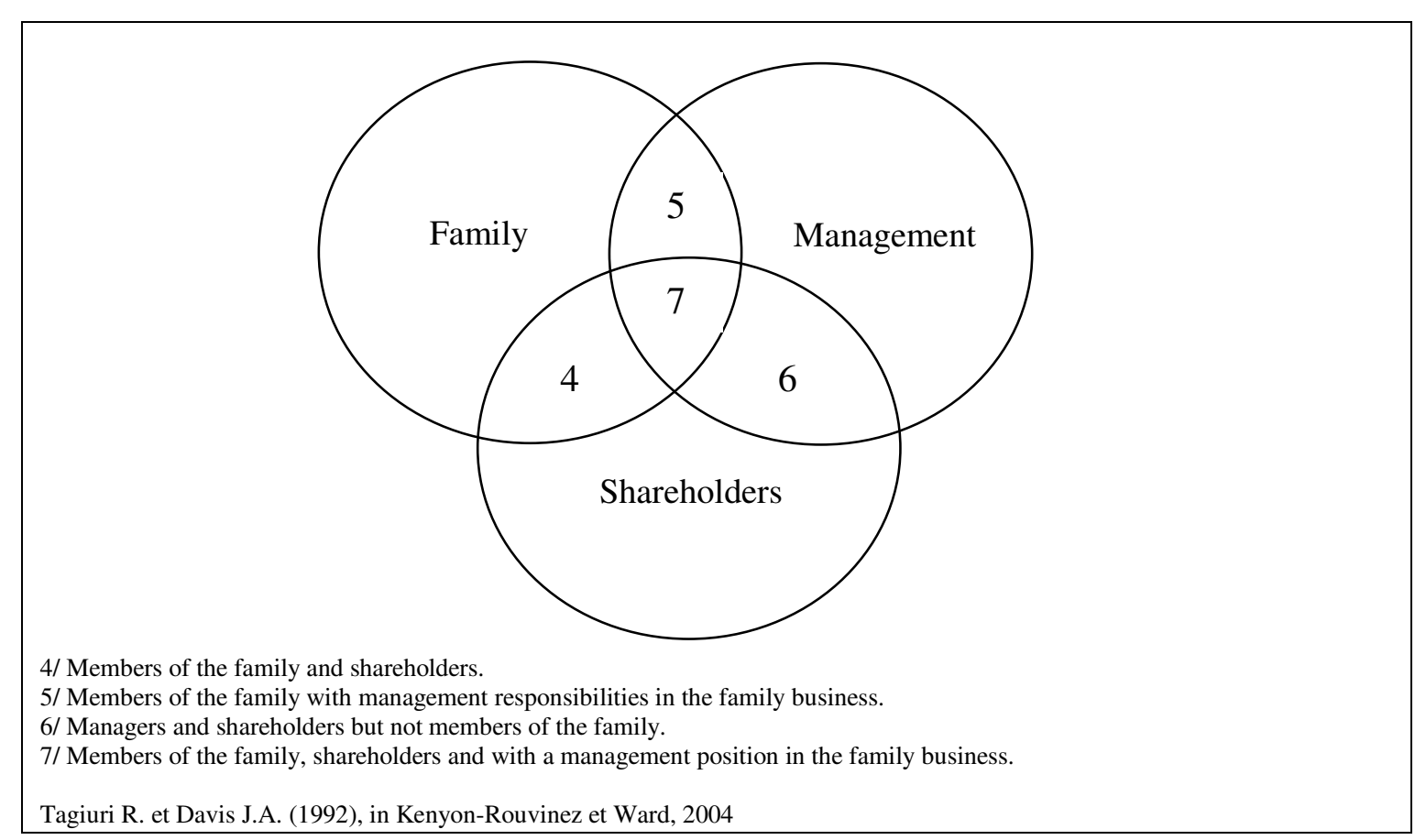

This systemic representation of the family business, with the three circles, progressively became a reference and is either explicitly or implicitly taken into account by other researchers such as Stafford et al. (1999), Olson (2003), Kenyon-Rouvinez and Ward (2004), Hirigoyen (2007a).

Stafford et al. (1999) propose a research model on the longevity of family business: the Family Business Research Model (FBRM). In this model, equal importance is being given to the family and to the business in order to understand the success of Family Business. Thus the role of the family in the success of the FB is 
acknowledged. There is reciprocity of influence between the two which explains its longevity.

In order to analyze the role of the family in the longevity of FB, Olson et al. (2003) use the model developed by Stafford (1999). These authors, as well as Arrègle et al. (2004) also refer to the family system described by Kepner (1993) and by Olson (1986). They use the latter to provide a better understanding of the role of family in the longevity of FB. This model, called the Olson circumplex has two dimensions: the degree of cohesiveness of the family as well the degree of adaptability of the family. Each of these dimensions has a scale of 1 to 4 . The combination of the two dimensions with the four scales enables Olson (1986) to identify 16 family types. According to the author, families which are at the extreme of the two dimensions are a threat to the family business (lack of cohesiveness and ability to adapt). This can be linked to the work of Olson and al (2003) according to whom, when the family of a FB is going through difficulties, this has a direct impact on the longevity of the business.

The resulting interactions between family and FB are given the name of familiness by Habbershon et al. (1999). They provide FB with specific resources which enable it to gain a competitive advantage over non family ones. As mentioned by Arrègle et al. (2004), if the family is a social institution which is meant to last, it will share long these term objectives with the FB and will positively influence its longevity. This link will be made stronger if the FB is embedded within the family institution through the presence of family members at management positions, through the active role played by family shareholders and through formal procedures through which family values are transmitted.

This intersection between the family system and the FB system also shows up in the personal commitment of the owner-manager of the FB, under the name of 
stewardship and is recognized as factor of longevity. This is also a manifestation of their selflessness but also of their long term global vision (Gersick 1997; Miller and Le Breton-Miler, 2005, 2006, 2011). This leads Hirigoyen (2007b) to write that the longevity of FB's lies in their ability to articulate the project of the family with the project of the business by exercising vigilance on the behavioral bias of the managers.

Amann and Allouche (2002) breach the subject of how FB's relate to stakeholders. They mention that in the case of FB trust plays a bigger role. Partners and stakeholders are treated, by extension, "as members of the family", with a long term approach to relationships. These authors propose to conceptualize the strategy of family businesses based on the development and the use of three social networks (family, internal, external) with reference to network theory. The longevity of family business would then correspond to the ability to develop and simultaneously activate these three networks with reference to Granovetter's embeddedness theory (1985). Robic (2007) also deals with this articulation concept by using Granovetter's embeddedness theory (1985). Based on the case study of a family business at a time of major change in the company's environment, she shows that strategic management, in such situations, lies on how different spheres or networks are inter-related. The family business will evolve based on how these networks will interact and on how they are embedded into one another. Thus, embeddedness is an explanation for strategic choices which may seem "paradoxical" from a strictly economic point of view, but seem "natural", relevant and efficient from a socioeconomic point of view. This goes beyond managing the intersection of systems with each other. It seems that the "Family Business" system is embedded in the "Family" system and that the two systems cannot be treated and analyzed separately from one another. The family system itself is embedded within its socio-economic environment and cannot be dealt with independently of it. 
We also identified a set of research work, led by Miller et al. (2005, 2006, 2011), Lumpkin and Brigham (2011), Ibrahim et al. (2009), Mahmoud-Jouini et al. (2010) which specifically focuses on the management of FB and not on the family + FB system. However, they show evidence that a long term perspective in decision making processes is an attribute of long standing FB's.

To sum up, part of the literature on FB adopts a systemic approach and looks at the family + FB system as a key to understanding their longevity as shown in figure 6 .

Figure 6. At the heart of Family Business longevity ... a quest for intersections or a hierarchy of embedded systems
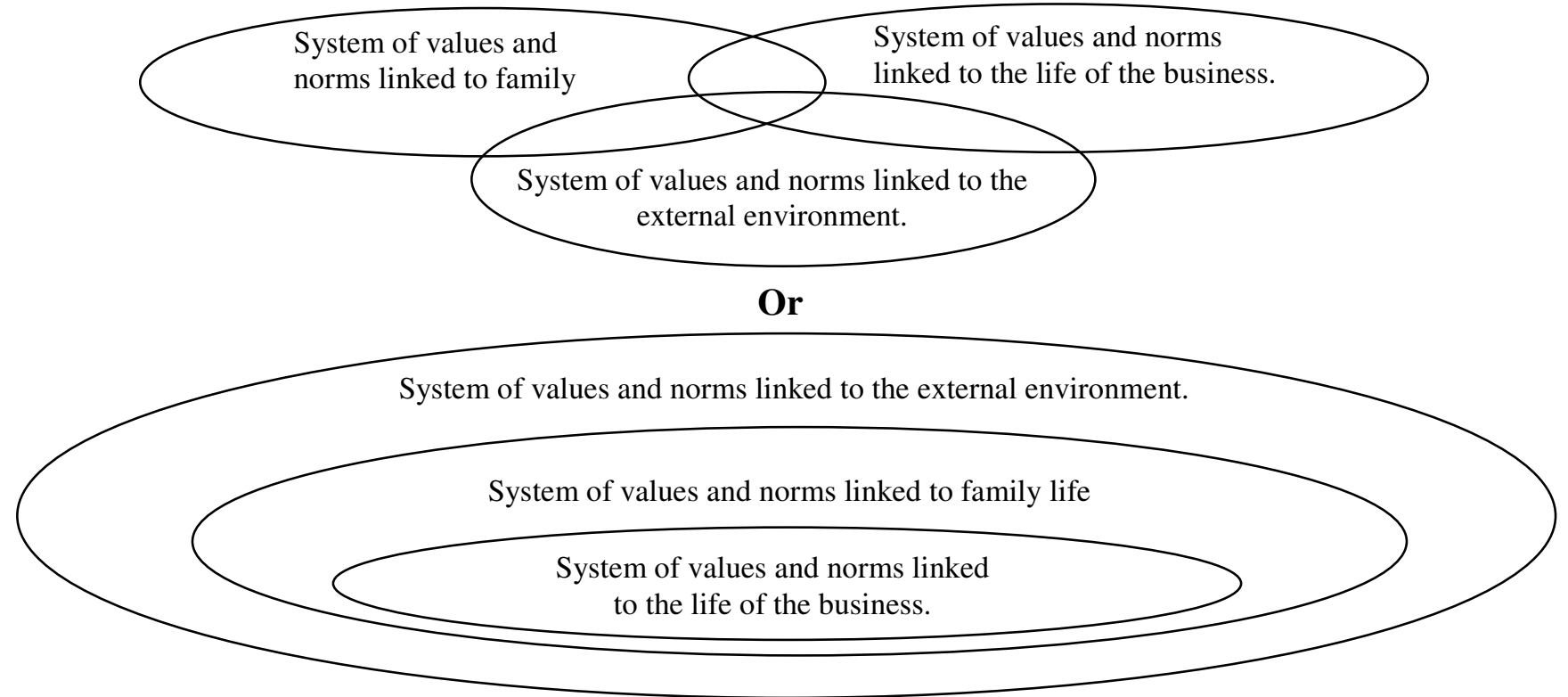

At this stage, we conclude that FB which have lasted, have a specific know-how in managing intersections, or imbrications, with a long term perspective. This is where the comparison with the literature on sustainable development (SD) becomes interesting and shows the common ground with the literature on FB longevity.

This led us to see if the interviews we conducted supported, or not, this systemic and long term vision we identified in part of the literature on FB longevity. 


\section{Part 3. Analysis}

In this part we conduct an analysis of the key elements associated with the longevity of the companies investigated. We focus on those elements which come up systematically for all six. We then attempt to identify if other characteristics, such as governance of the business and governance of the family can provide complementary explanations. In the end we propose a model which puts the elements we identified in relation with each other and with outcomes in terms of longevity.

Concepts associated with longevity: anchorage, areas of expertise and system of values

Table 4 sums up the key elements associated with the longevity of the businesses we studied. One will notice that the longevity of each business can be explained by a combination of specific, contingent factors, and by factors which come up in all cases.

We made a choice to focus on the issues which come up systematically because they played a role in the six businesses, in spite of their diversity, and not in just a few of them. This choice does mean that we disregard the specific factors as unimportant. Some key factors which come up only in one or two businesses were extensively discussed in the interviews and took up a lot of space ... but more space would have been needed to discuss them in this article.

We shall explain the meanings we associated with these recurring key elements, based on our analysis. 
Table 4. Key words associated with the longevity of each of the businesses investigated

\begin{tabular}{|c|c|c|c|c|c|}
\hline Carioll & Build O'shell & Vandamat & Furnishwell & Bon Manger & Bulldoze \\
\hline $\begin{array}{l}\text { An orderly, self } \\
\text { supporting, } \\
\text { business owner. } \\
\text { The type of } \\
\text { product / a } \\
\text { choice } \\
\text { specialization. } \\
\text { Role of the } \\
\text { spouse. } \\
\text { Simplified } \\
\text { family } \\
\text { situation. } \\
\text { Anchorage in } \\
\text { the territory } \\
\text { and the sector } \\
\text { Areas of } \\
\text { expertise } \\
\text { System of } \\
\text { values }\end{array}$ & $\begin{array}{l}\text { Sense of duty of } \\
\text { the business } \\
\text { owner. } \\
\text { The type of } \\
\text { product / a } \\
\text { choice } \\
\text { specialization. } \\
\text { Role of } \\
\text { historical } \\
\text { employees. } \\
\text { Swarming. } \\
\text { Anchorage in } \\
\text { the territory } \\
\text { and the sector } \\
\text { Areas of } \\
\text { expertise } \\
\text { System of } \\
\text { values }\end{array}$ & $\begin{array}{l}\text { Investment in } \\
\text { family values } \\
\text { and relations, } \\
\text { beyond } \\
\text { conflicts. } \\
\text { Formalized } \\
\text { family } \\
\text { relations. } \\
\text { Values of the } \\
\text { company. } \\
\text { Proactive } \\
\text { strategy. } \\
\text { Anchorage in } \\
\text { the territory } \\
\text { and the sector } \\
\text { Areas of } \\
\text { expertise } \\
\text { System of } \\
\text { values }\end{array}$ & $\begin{array}{l}\text { Investment in } \\
\text { family values and } \\
\text { relations, beyond } \\
\text { conflicts. } \\
\text { Fighting spirit of } \\
\text { the business } \\
\text { owner, strong } \\
\text { will to survive. } \\
\text { Network of the } \\
\text { business owner. } \\
\text { Role of the } \\
\text { spouse and of the } \\
\text { family house. } \\
\text { Reaction of the } \\
\text { employees at a } \\
\text { time of crisis. } \\
\text { Anchorage in } \\
\text { the territory and } \\
\text { the sector } \\
\text { Areas of } \\
\text { expertise } \\
\text { System of values }\end{array}$ & $\begin{array}{l}\text { Complementarity } \\
\text { of the husband } \\
\text { and wife who } \\
\text { founded the } \\
\text { company. } \\
\text { Creativity of the } \\
\text { husband. } \\
\text { The company } \\
\text { operates as a } \\
\text { tribe, with closely } \\
\text { knitted family } \\
\text { members. } \\
\text { Two way } \\
\text { communication } \\
\text { with employees. } \\
\text { Proactive and } \\
\text { daring strategy. } \\
\text { Anchorage in } \\
\text { the territory and } \\
\text { the sector }\end{array}$ & $\begin{array}{l}\text { Investment in } \\
\text { family values } \\
\text { and relations, } \\
\text { beyond } \\
\text { conflicts. } \\
\text { Formalized } \\
\text { family } \\
\text { relations. } \\
\text { Strong local } \\
\text { network. } \\
\text { Role of } \\
\text { historical } \\
\text { employees. } \\
\text { Proactive } \\
\text { strategy. } \\
\text { Anchorage in } \\
\text { the territory } \\
\text { and the sector } \\
\text { Areas of } \\
\text { expertise } \\
\text { System of } \\
\text { values }\end{array}$ \\
\hline
\end{tabular}

Anchorage in the territory and the sector

We noticed how the persons interviewed made strong references to the home territory of the company and to their networks. This gives them a knowledge base and a sensitivity which they feed in the decision process of their business to make their company evolve, fit with its environment and stay anchored in it. The quote in figure 7 is interesting because in less than one minute the Chief Executive Officer of Furnishwell moves from his idea of anchorage in his business sector to the one of anchorage in his business' home territory. The link between the two is personal relations. 
Figure 7. Anchorage in the sector and the territory

Well, yes, we think that we cannot live without knowing people well. So my duty, even if I am not involved in the details of commercial negotiations, as we have teams for that, is to get to know well the top Management of But and Confo (major French furniture retailers). When I mean to know them well, I mean it. Me, and the president of Confo, we dine with each other three times a year. And it is the same with the President of But. My aim is that we get to know each other well and can have an open communication channel: we can tell everything to each other.

As I told our employees during the annual meeting, some companies are moving away, but we will stay. We are not even French. We are from Vendée, we want to stay in Vendée and we will stay in Vendée.

What is different from the management of other companies ] non family businesses [ is that I was born here. I am from here. And even if it will surprise you I have super mates from the village with which I play cards. They are employed on our factory production lines. ]... [ They are former school mates.

Mr. Wood. Chief Executive Officer of Furnishwell

The persons interviewed are constantly on the lookout and develop sensorial abilities which enable them to "feel" very early shifts in their environment, detect threats or opportunities for their company and react extremely fast upon these perceptions. This seems to concern their family environment, their professional environment and the economic and social one which surrounds them. It does seem that they are "embedded" within their environment through personal and professional networks, a daily curiosity and a lookout for everything that concerns their company. We cannot conclude that this is only the case of family businesses owners. However it is already quite striking to identify this ability in the six businesses investigated. At a time of crisis, the speed with which immediate changes can be decided is also striking. Let us look at a few examples.

In the 1960s the owners of Build O'Shell saw the need to implement formal management tools and procedures. They made the most of training courses which were being set up by the French Building Federation (and which still exist today). At the time, alongside with training courses, the French Building Federation had developed computerised cost calculation tools The father of the present owner and three of its recently recruited managers followed these courses and put into place the company's 
management control tools which still form the backbone of the company's cost calculations today. In turn these tools led the company to specialize itself, first in the field of concrete buildings, then exclusively in the structure of large concrete buildings (figure 8).

Figure 8. The development of management tools at Build'o Shell, based on opportunities offered by professional networks, and their influence on the company's strategy

Yes, and this contributed to the development of the company because at the time, there were many activities. We worked for companies, because at the time well known companies such as Jeannot, Griffon, Gauthier were growing. The company worked for these people and many others whose name I forgot. We also built concrete individual houses and then buildings. At the time already we were not doing any renovation work anymore, or hardly any. Our management control tools enabled us to see that some activities were more profitable than others. This contributed to the specialization of the company in the field of reinforced concrete buildings.

Mr. O'Shell, owner and chief executive director of Build O'Shell

This coincided with a time when populations in France, in suburban areas, were increasing fast and when large buildings needed to be completed fast. From 1947 to 1958, construction of buildings in France rose from 70000 to 320000 buildings a year and stayed at this high level for the next decade, fuelled by such factors as demographic expansion, the dismantlement of temporary buildings constructed after second world war and the arrival of immigrant labour. French authorities at the time clearly encouraged the construction of large collective buildings ${ }^{\mathrm{iv}}$. Build O'Shell specialized at the right time at the right moment on a segment where there was a huge demand and fast growth. Today, at a time when environmental concerns are a key question, along also with cost cutting initiatives, the company is working on concretes that will reduce energy consumption of the building through better isolation. It has also developed prefabrication methods for some the structural elements of a building, in order to produce them off the building site at a lower cost and transport them on site for 
assembly. This saves costs as it avoids moving equipment to different sites and centralizes some of the production. A subsidiary was created in order to spin off this new business and make it possible to sell its production elements to other companies, even competitors of Build O'Shell.

This ability to move with the environment, in the right directions can also be linked with a capability to project long term perspectives. For example, in the first interview carried out with him, Mr Carioll is asking himself whether the products or services provided by his company will still be needed in thirty to forty years, and what technologies will enable this to happen. He believes it is his duty to ask himself such questions and belongs to clubs of family business owners which invite specialists to help them think the future. It is with a similar projection in mind that, in the 70's, after a trip to the United States, he and his brother decided to focus production on an entirely new type of leisure vehicle. This choice turned out to be totally in line with upcoming tendencies in terms of leisure, mobility and aging of the population, some of which are still producing effects today. Thus, press articles of the time, which we consulted, relate the history of Carioll as a dynamic family business, which managed a successful and rapid transition from a traditional activity to a new emerging one so as to become one of the leaders on this market.

At Bon Manger, it was also striking to notice how the owners presented us the history of their company. Every single important evolution of the business in terms of investment, marketing and product-innovation was systematically put into the context of evolutions in the company's environment. Beyond the actual story that was shown to us, it was interesting to notice the mindset which the owning family was displaying (Figure 9). 
Figure 9. Drawing parallels between how the environment evolved and how the company evolved. The case of Bon Manger

One of the daughters: We have tried to present the history of Bon Manger so as to draw a parallel between evolutions in the environment and evolutions within our company.

\section{]...[}

One of the daughters: From 1981 to 1992 we were already talking about the beginning of the low cost years. As early as 1988 we saw the opening of the first discount retail stores such Lidl in Germany. This is also the beginning of globalization as it is being described today, with the fall of the Berlin wall and what ensued, and the development of internet. This fundamentally changed work habits and life styles. It is also the beginning of global crises such as the AIDS crisis. If we talk about this, it is because it these global crises had important consequences in terms of regulation, and over regulation for the agri-food industry. The part of food falls down to $19 \%$ in the expenses of households and falls prey to cuts. When such expenses as housing ones cannot be compressed, the food budget suffers from cuts. As far as we are concerned, it is at this stage that we developed our offer of ready-made, self-service, off the shelf products ] to keep in line with evolving life styles [.

The mother: This corresponds to the time when you joined the business. You developed this line of business because we were not good at it.

One of the daughters: We became pioneers in the ready-made catering segment. At this time this segment was made up of delicatessen products. We also diversified into salads and sandwiches but at the time we were such precursors that it did not work. This is a time when we heavily invested in TV advertising so as to push the development of our self-service delicatessen/catering segment. We are so glad we started advertising that early because it takes time to build a brand and we are reaping the fruits of it just now..

Interview with the Bon Manger founders and their three daughters.

The material we collected supports the idea that owners view their businesses as embedded in their socio-economic environment. In no way is the company seen as separate from its environment but as an entity which lives from it and in it. This is in line with the embeddedness metaphor identified in our investigation of SD, in which economic activities are a subset of society. However only in one or two cases did we have elements from the interview which show that they also realise that society itself is a subset of eco-systems.

What we identified in the interviews also supports the research we identified in FB longevity under the name of stewardship We did identify expressions of selflessness 
and a preoccupation for the long term which echoes the work of Gersick et al. (1997), Miller and Le Breton-Miler (2005, 2006, 2011).

Well defined areas of expertise, interdependency and an ability for coordination

Whenever the theme of power sharing arrangements came up in the interviews, conflicts were a part of them. What came out, as a solution to resolve these conflicts and avoid future ones were solutions through which each member has well defined areas of expertise and does not encroach on the others. In some cases, this rests on a mutual understanding which was passed on from the previous generation (figure 10). In other cases, a lot of negotiation was involved in defining deals, and contracts were involved (figure 11). Longevity rests on the ability of each member to manage his area of expertise with competence, on mutual trust between family members and on their ability to coordinate with each other. This concept goes beyond corporate governance. Here is how it materialized in the companies we investigated.

At Carioll, only one member of the family, the main shareholder and chief nonexecutive officer, is on the pay-roll. Thus, there are no family conflicts which can be exported to the company. However, in the company, there is an executive managing director which oversees company operations. Mr Carioll sticks to his general supervisory role, to high level relationships with banks and to the role of company public figure. He successfully imposes himself the discipline needed not to encroach on the operational mission he has delegated to his executive managing director. According to Mr Carioll, the two men are complementary, and have respect for one another.

At Build o'Shell, Mr O'Shell, a manager by training owns half the shares. His cousin owns the other half. Mr O'Shell oversees general management, customer relationships and prospecting. His cousin, who was trained as a building professional is 
the technical executive manager. He oversees all that is technical and supervises the building sites where the company operates. The father of Mr O'Shell and his two brothers had devised this separation of tasks and their sons adopted it (Figure 10).

Figure 10. Three brothers who do not agree with each other, but who work well together So after this, when they took over the company my husband became the director. He learnt it on the job and also through training. But everything was kept separated. The three brothers each had their own role to play in the company. My brother was a construction site manager and was really so good. He invented extra-ordinary techniques which enabled the three of them to bid for the construction of large buildings, which they still do now.

Mrs. Jeanine o'Shell, mother of Mr. O'Shell

At Bulldoze, the executive committee is chaired by the person we interviewed who acts as CEO and the supervisory board is chaired by his brother. The CEO and his brother have also devised another power sharing arrangement. One is in charge of developing the business, the other one is in share of developing family bonds with the business with such events as the "Bulldoze University" which we will mention at a later stage. Once again, this arrangement was devised to avoid the two brothers from encroaching on one another. Although conflicts visibly arose (figure 11) it was not to the extent of pulling the company apart. We will come back later to why conflicts did not have a fatal consequence for the business.

Figure 11. A transmission to the next generation and a negotiated power sharing deal at Bulldoze

And then, in 97, from 97 to 2000 , they, ... well they put themselves in the ... Well, we took over. From 97 to 2004, Pierre-Marie Bulldoze was Chief Executive Officer and Chairman of the board, and in 2004 we changed things and prepared for transmission. We turned the company into an entity with a board of supervisors and an executive committee.

At this time I became President of the executive committee and my brother became President of the board of supervisors.

Er ... it took a lot of explanations ... er, er, tough ones, with the signature of pacts. Oh, well, there is no, there is no ... it can be done.

Mr. G.A. Bulldoze. Chief Executive Officer 
At Furnishwell, the upcoming generation was invited in such a way that it found a place in parts of the business which were developing, where they were not taking somebody's place. The four children of the current owner and CEO are in the business. One of them is in charge of expanding export activities; one of them is overseeing the development of franchisees in France, a recent strategic choice; yet another one has technical responsibilities and the elder son, at 40, is being groomed in view of becoming CEO.

At Bon Manger, it is also interesting to notice that the three daughters of the founders found their place through the development of the company. They initiated advertising strategies to build the company brands. They expanded the line of products and oversaw the growth of business relationships with chains of supermarkets and hypermarkets. Their parents gave them their freedom in a field which was needed in order to expand the company and ensure its longevity, while remaining, to start with, at the head of the company. This is partly illustrated in figure 9.

What seems to emerge from the interviews is a high level of organized interdependency between family members, but also between family and non-family members. This interdependency rests on well defined areas of expertise which give each participant enough freedom, yet which make interaction and coordination with other members needed in other to succeed. The danger would be that participants do not manage to interact, or do not have the skills needed to manage their area of expertise. This shows up in two of the ten case studies with which we contrasted our work but apparently, not in the six companies we studied. They probably benefited from favourable conditions but also owe their longevity to a real know-how in conflict prevention through setting up inter-dependent, but well defined areas of expertise. This 
skill is also reinforced by specific transmission preparations which we will mention later on.

The material collected in our interview supports the intersection metaphor identified in our investigation of the SD concept. The areas of expertise we identified are defined clearly enough to be identified as separate entities, yet the family business as a whole can only work through interaction between the members in charge of these areas. What we identified also comes in resonance with the familiness concept of Habbershon et al. (1999). At least in five of the six businesses many members of the families were embedded into the business in different manners: through top management positions (Bon Manger, Build'O Shell, Furnishwell, and Bulldoze) and/or active participation in the supervisory boards (Bulldoze, Vandamat). Because they have devised ways to work together, through the values they instill in the business, they contribute to the intersection of family and business interests.

\section{System of values}

We identified similarities, across all six companies, on values as regards anchorage in the territory, cautiousness, employees and long term perspectives.

To start with the persons interviewed presented employees as assets. This is illustrated by figure 11. In some cases it is also shown in descriptions of the role played by historical employees in grooming successors, when there is a transition from one generation to the next.

We also noticed that the persons interviewed systematically displayed an ability to think in terms of long term profits, even if this is at the expense of short term ones. Once again, this is illustrated by figure 11 and as well, partly, by figure 9 , where we are 
told that advertising strategies decided in the 80's and 90's are now beginning to generate brand awareness.

However, in the companies which had a hard time during the 2009 crisis this mindset is more nuanced. This is the case of Build O'Shell and Carioll, For Mr O'shell, these values are deemed to be «old-time company values which are disappearing with the crisis ». For Mr Carioll, a business owner and manager is not an angel. He admits that during the crisis he made choices which created disillusion and damaged the reputation of his company and of business in general. However radical choices had to be made, in order to ensure survival, and this partly separated the company from society (dismissals, discarding of long time suppliers ...). Although this saved the company in the short term but, it lost connexions with its environment which will take time to rebuild. This is especially the case with young jobseekers. For example, when economic growth came back again, it proved difficult, and even impossible, to recruit again those youngsters who had been dismissed, even if they were still looking for a job. In the other companies which did not suffer financially too much from the crisis, we noticed more "openhearted" generosity and a will not to sacrifice long term capabilities over short term profit, especially if the company can afford it.

All in all, regardless of the hard or easy times these companies had been through, we did identify a mindset of interdependency and embeddedness with society and the conviction that staying connected to society is a way to guarantee long term profitability. This supports the embeddedness theory approach proposed by Granovetter (1985). 
Figure 11. Relationships with stakeholders and employees, the case of the Vandamat company through the 2008-2009 crisis.

We told ourselves, considering the corporate culture, considering the fact that this crisis is not structural, and considering the fact that we are capable of resisting that we would carry out small adjustments, at the margins but not mass dismissals.

Of course, this decision will have an impact on the company income. Of course, if we can save money on some positions in the company ] through dismissals [ and if we don't do it, our income will decrease. It seems legitimate to share such choices with shareholders. So we talked about it, very clearly. And we debated what to do. Do we organize mass dismissals? We will generate social unrest and damage, and may be save a bit of money. On the contrary, should we tell ourselves that we have a pool of skills within the company and that we should preserve it and at the same time be more demanding with the people we keep, when for example, they don't arrive on time.

We shared this debate with the shareholders and we did what we had to do. That's all. So our income is slightly lower this year. We did save on personnel costs because income based incentives went down and because we did not renew a certain number of short term contracts, but we did not carry out mass dismissals. And we did tell the employees that we were going through a storm, but that everybody was staying on board, and that everybody had to make efforts. Wages were frozen, bonuses went down because, arithmetically, they are linked to income, and when income falls, they fall. Wages went down in 2009 but we did share with employees that our choice was to keep everybody on board. Of course, this can only be done if the shareholders and the executive management share common values and a common vision of where the future of the company lies.

Mr Joss, Chief Executive Officer of Vandamat, non-family member

\section{Looking for other explanation through common organizational factors such as corporate governance, family and family business relationship, transmission protocols}

After identifying common longevity factors in the six businesses, we looked for organizational, structural characteristics which might in turn explain these factors. We then asked ourselves the question of which companies might successfully be transmitted to the next generation and why.

\section{A diversity of corporate governance modes: no explanation of longevity}

We tried to define the corporate governance of these companies in a simple manner by combining two criteria. The first one is the presence, or not, of a non-family chief 
executive officer. The second one is the presence, or not, of non-family members in the supervisory entities (board of administrators, supervisory committee, depending on the legal status). The situations we observed are described in table 6 . There is quite a diversity of situations and, when there is more than one company for a given situation, these companies do not look alike at all.

Table 6. A diversity of governance modes

\begin{tabular}{|l|l|l|l|}
\hline \multicolumn{2}{|l|}{} & \multicolumn{2}{|c|}{ Non family members on the board } \\
\cline { 3 - 4 } & Yes & No \\
\hline $\begin{array}{l}\text { Non family Chief } \\
\text { Executive Officer }\end{array}$ & Yes & Hybrid \\
\cline { 3 - 4 } & No & $\begin{array}{l}\text { Open } \\
\text { Carioll } \\
\text { Vandamat }\end{array}$ & $\begin{array}{l}\text { Closed } \\
\text { Bulldoze } \\
\text { Build'o Shell } \\
\text { Bon Manger }\end{array}$ \\
\cline { 3 - 5 } & & $\begin{array}{l}\text { Hybrid } \\
\text { Furnishwell }\end{array}$ & \\
\hline
\end{tabular}

For example, as concerns companies with “open” governance systems, Carioll is a strictly family-owned business, with only one branch of one family owning the shares. As for Vandamat, a good third of its shares are listed on the stock market and two families own most of the rest. As concerns companies with "closed" governance systems, they also have different characteristics despite the fact that they are in the same category. As for the only company we described as hybrid, we know that, in the past, it had to seek external investors and creditors in order to free itself from the control of an investment fund. The family is planning to take back full control and this company should evolve towards a closed system of governance. 
Our sample of six businesses is reduced and we definitely are not inferring any statistical conclusions from it. However, we draw from it the information that there is not one typical model of governance which supports or favours the key factors we identified in our analysis of longevity.

\section{Regulations modes between family and business}

In order to push our analysis further and identify organizational factors which would explain longevity we asked ourselves the following question: which of the companies investigated would make it to the next generation and why? As previously done each co-author conducted his analysis and wrote his justifications separately from the others before sharing them. This was done in order to focus ourselves not on past longevity but on factors and/or systems which would ensure longevity in the future, and to make our assumptions explicit.

By making explicit why we thought some businesses would make it to the next generation and why some would have more difficulties, we identified two very important criteria. The first one is the existence, or not, of formal rules which regulate how family members relate to the business (written rules, pacts, and codes to be respected, contracts signed between family members). The second one is the extent to which transmission to the next generation is planned, and carried out through the symbolic enrolment of heirs in "emotional" experiences which involve celebrating the family business' longevity and future. Some of these "enrolment" procedures are very formal and materialize themselves through the existence of structures explicitly dedicated to transmission. Table 7 sums up our typology based on these two criteria. We named "dynastic systems" those family businesses which had both formal family relationships and transmission rules and structures. We named "tacit systems" those companies which, although they had no formal system of relationship, displayed a 
strong will to prepare the next generation. Although no formal structures exist, in tacit systems, children are invited for visits and take part in family meetings during which the family business is at the centre of discussions. We then named "based on free will of heirs" those companies which did not have formal rules stating how family members should relate to the business and in which, it seemed that family heirs were not symbolically "enrolled" in the company's future through meetings, celebrations or other emotional experiences.

Table 7. A diversity of regulation modes between family and business, the specific of case of transmitting the business

\begin{tabular}{|l|l|l|l|}
\hline \multicolumn{2}{|l|}{} & \multicolumn{2}{|l|}{$\begin{array}{l}\text { Symbolic, emotional, enrolment of the } \\
\text { future generation into the future of the } \\
\text { business. }\end{array}$} \\
\cline { 3 - 4 } & Yes & No \\
\hline $\begin{array}{l}\text { Formal relations } \\
\text { regulate } \\
\text { relationship of } \\
\text { family members to } \\
\text { the business }\end{array}$ & Yes & $\begin{array}{l}\text { Dynastic } \\
\text { Bulldoze } \\
\text { Vandamat }\end{array}$ & $\begin{array}{l}\text { Based on free will } \\
\text { of heirs } \\
\text { Build o'shell } \\
\text { Carioll }\end{array}$ \\
\cline { 2 - 4 } & No & $\begin{array}{l}\text { Tacit } \\
\text { Bon Manger } \\
\text { Furnishwell }\end{array}$ & \\
\hline
\end{tabular}

All the companies for which the co-authors were sure that there would be a successful transmission to the next generation had dynastic systems, or tacit ones. The companies for which we had reservations had a system based on the free will of heirs. Thus, we conclude that the symbolic enrolment of the future generation in the family business, at a very early age, through emotional experiences, is a key factor to ensuring longevity.

To provide an example, let us take a look at the enrolment system put into place at the Bulldoze company. The Bulldoze brothers and cousins of the $4^{\text {th }}$ generation were 
pushed by their parents to create a public works company and to run it as a team. The company owned one bulldozer and had to win and carry out contracts for the family business. As they were running this business, the brothers and cousins were being provided with tailor-made business administration courses provided by the company's auditors and managers, under the supervision of their parents. Very early the $4^{\text {th }}$ generation members were socialized in a context in which they had to share ownership and management of a company. On a smaller scale, they went through what their parents lived, learnt the ropes and created bonds with each other. As for the $5^{\text {th }}$ generation, it is through a "Bulldoze family university" that they are enrolled in the company's future. The program of this university is a combination of on-site visits of the Bulldoze companies, training sessions and active participation at the shareholders' meetings through the symbolic ownership of a small amount of shares in the company. Some of the activities of this program target different age groups so that even 10 year old children can feel involved. We believe that this early emotional enrolment prevents conflicts from being solved at the expense of the family business. Members of the upcoming generation learn to work with each other very early and test each others' limit. The emotional investment they have put into the business prevents them from using it as weapon against other family members.

Theoretical models have been proposed to deal with succession. Lubinski (2011) has identified two. The first one is Floeren's model (2002) which distinguishes “presuccession," "succession," and "post-succession" periods. The second one is Cadieux's (2007) which identifies "initiation," "integration," "joint-reign," and "withdrawal" as the basic steps of every succession process. This emotional enrolment we have identified supports the idea of organized "pre-succession" and 'initiation' phases. Our findings also support Lubinski argument of a process which is planned and shaped by 
the actors involved. It also supports her use of the anticipatory socialization concept which she borrows from sociologists and develops in a case study. She shows how social and cultural capital is transferred to the successors to lead to shared beliefs, over a long period of time, beyond the specific succession process. Our results also relate to the theory of psychological ownership which has been discussed among others by Pierce et al. (2001), Hall and Chandler (2005). These authors show that if next generation members feel they are a part of the business, they will be enticed to make decisions which will preserve the long term interests of this business and also their well being. The processes put into place by the Bulldoze family for the $4^{\text {th }}$ and the $5^{\text {th }}$ generations are fitting examples of how this sense of ownership is being developed in a formal way. On the negative side, successors may be affected negatively by what they see as an obligation to accept this shared ownership, which is a burden for them. This showed up most in the companies were succession processes were the least codified (Carioll, Build O'Shell).

\section{Conclusion of Part 3}

To conclude this analysis, despite the fact that we had six very diverse businesses in our sample, we did identify three factors which were valid in all six companies, alongside with specific factors. If we focus only on these common factors it seems that the longevity of family businesses is associated with two distinct processes.

The first process is the governance of relationships between family members and the family business. Long lasting companies have developed an ability to manage conflicts and contradictions between these two spheres by four means: 
- the adoption of formal, codified rules between family members. This has been observed in the companies which had at least known three successful transmissions;

- the adoption of areas of expertise, a means of sharing power that combines autonomy and interdependency; this has been observed in the six companies;

- emotional enrolment in the company at an early stage; for each of the persons we met, the FB is somehow a master piece they inherited or created and they feel a duty towards it. In the oldest companies such as Bulldoze and Vandamat, specific processes aim at generating such emotions and bonds between members of the same generation;

- the fourth one is the self effacement of individuals who accept involvement in the family business, not always willingly, but as something inevitable.

The second process is the decision making one which favours decisions that increase financial, economic and human capital. This is the consequence of values shared by decision makers: cautiousness, a preference for long term profits, anchorage within the sector and the home territory, loyalty to employees who are treated as assets, and interdependency as created by areas of expertise.

These processes contribute to two abilities: the ability to manage conflicts/contradictions and the ability to accumulate capital. These abilities contribute to a successful transmission to the next generation.

The above conclusion of our analysis is summed up in figure 12. Oval shapes are elements which are to be found in the interviews. The rectangular shapes represent how we grouped these elements into categories. The semi-oval shapes represent groups of categories. The diamond shapes are outputs which explain longevity and, in the end, successful transmission to the next generation. 
Figure 12. Analysis of the interviews and link with outcomes in terms of longevity

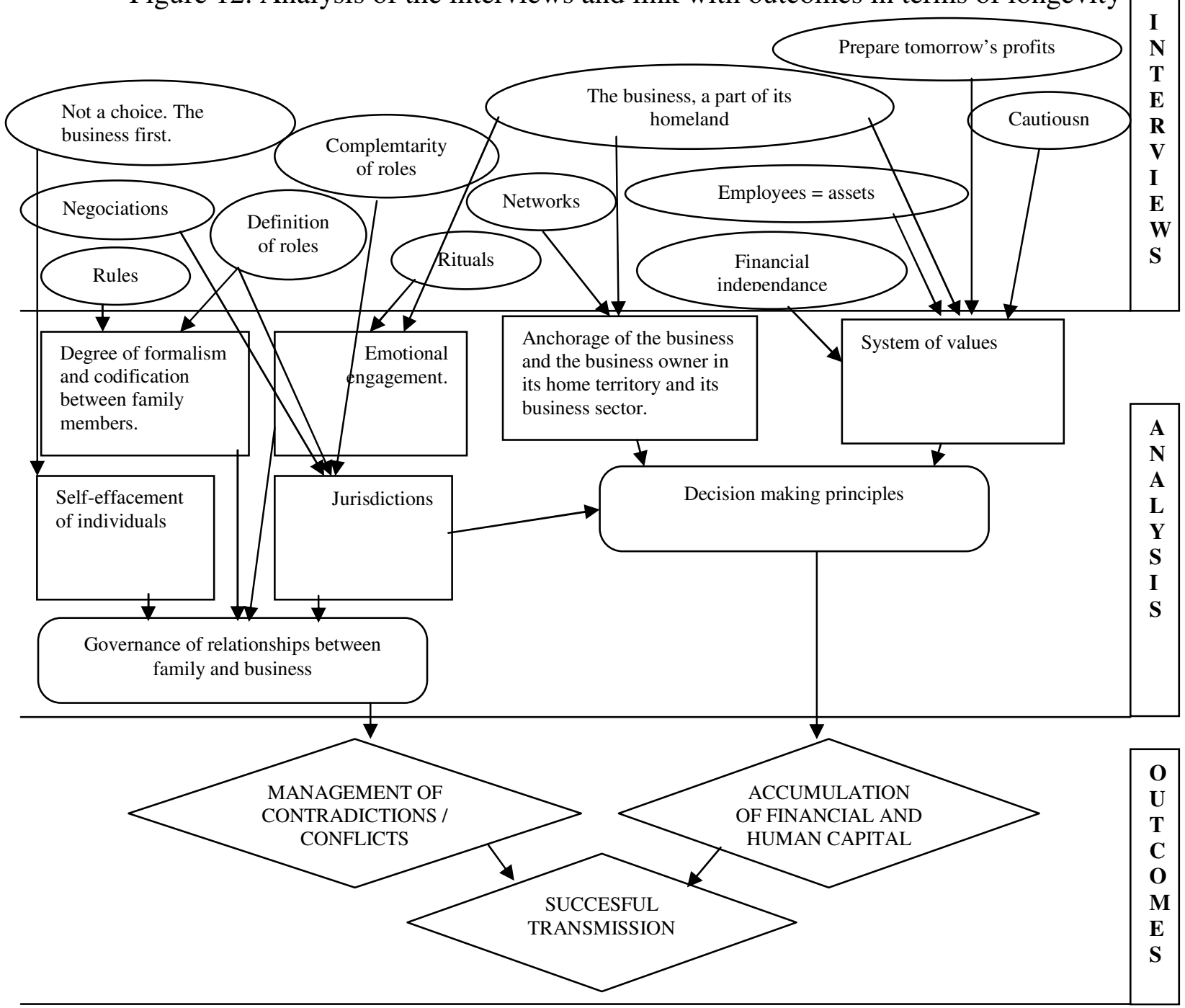

In our conclusion below we come back to the literature and we analyse which part of the

literature supports our model. In a very broad manner, we express an opinion on whether long lasting family businesses have been conducting sustainable development long before it became a fashion.

\section{Conclusion}

As a (temporary) conclusion to our research, the evidence collected in the interviews supports the idea that family business owners, whose businesses have been around for more than two generations, constantly seek a common ground between:

- family and business interests, 
- the business, its stakeholders, it socio-economic environment,

- power sharing between family members and coordination,

- present and future, with the idea of passing on the business to the next generation and seeking long term, rather than short term profit.

The family businesses we investigated seek intersections, especially when, through areas of expertise, they manage power sharing deals which combine the autonomy of family members involved in the business with a need for coordination through interdependencies.

However, when it comes to relationships with the socio-economic environment, the dominating mindset is that of a company embedded in its environment and within its community, presented as a pool of resources and a source of economic growth. Business owners are constantly on the lookout. Interviews suggest that they have an ability to feel evolutions and to react quickly in order to make their companies evolve. The ten case studies we contrasted our work with emphasize this ability of long lasting FB to seek a common ground between the business, the family, the socio-economic environment, even at the expense of short term profit and with the aim of preserving long term capabilities and transmission to the next generation. Only if grave crises occur and if no such common ground is possible, will the business adopt short term expedients in order to ensure its survival and sever itself from its environment ... at a cost.

Thus, it seems that interdependency and connectedness of different spheres, embeddedness of the family in the business and of the business in society, transmission of a capital to the next generation are key concepts to FB longevity. This mindset does correspond to a sustainable development approach, as identified in our review of literature on $\mathrm{SD}$, except may be when it comes down to expressions of how society is embedded within eco-systems. It is different from the eco-efficiency perspective that it 
usually associated with business when it comes down to sustainable development. Furthermore, as mentioned in part 3, our findings also support the results of FB researchers who have identified the notions of familiness, stewardship, embeddedness and psychological ownership as key longevity factors.

It is striking however to see that this comes at a cost for some family members, who do not have a choice, who feel enrolled in the family business against their will and feel their individual freedom has been sacrificed. This is the negative side of psychological ownership which we mentioned earlier. Longevity, it seems, puts the business and the family first, and family members do not have much freedom as individuals. In our research this appeared to be the case in the companies where the succession process was the least codified. Is it necessarily so? We do not have big enough a sample to answer this question. This is a lead for future research which we would like to explore. Another lead for research we aim to pursue would be to come back to the specific longevity factors that we identified in each company and develop detailed case studies to explore them, so as to see how they challenge the model we came up with.

\section{References}

Allouche, José and Bruno Amann. «L'entreprise familiale: un état de l'art.»Finance Contrôle Stratégie, 3, (1) (2000): p 33-79.

Allouche, José and Bruno Amann. «L'actionnaire dirigeant de l'entreprise familiale. » Revue Française de Gestion, 5, (141) (2002): 109-130.

Arrègle, Jean-Luc, Rodolphe Durand, and Philippe Very. «Origines du capital social et avantages concurrentiels des firmes familiales », M@nagement 7, (1) (2004) : 13-56.

Blanchet, Alain, and Anne Gotman. L'enquête et ses méthodes. L'entretien. Paris: Armand Colin, 2005.

Blondel, Christine, and Anne Dumas. L'entreprise familiale sauvera-t-elle le capitalisme? Paris : Autrement Editions, 2008. 
Cadieux, Louise. "Succession in Small and Medium-Sized Family Businesses: To-ward a Typology of Predecessor Roles During and After Instatement of the Successor." Family Business Review 20 (2) (2007): 95-109.

Colli, Andrea and Mary Rose. "Family Business." In The Oxford Handbook Business History, ed. Jones, Geoffrey, and Jonathan Zeitlin, 194-217 Oxford, Oxford University Press, 2007.

Colli, Andrea, Paloma Fernandez Pérez and Mary Rose."National Determinants of Family Firm Development? Family Firms in Britain, Spain, and Italy in the Nineteenth and Twentieth Centuries.” Enterprise \& Society 4 March (2003):28-64.

Daumas, Jean-Claude. «Famille et entreprise en France pendant les Trente Glorieuses (1945-1975). » Paper presented at International Economic History Conference, Helsinki, Finland, August 21-25, 2006.

Davis, John and Guth Tagiuri. "The Advantages and Disadvantages of the Family Business." Paper presented at Owner Managed Business Institute CA, Santa Barbara, U.S.A, 1982.

Davis, John, and Guth Tagiuri. "On the Goals of Successful Family Companies." Family Business Review 5 (1) (1992): 43-62.

Faccio, Mara and Lang, Larry, H.P. “The Ultimate Ownership of Western European Corporations" Journal of Financial Economics, 65 (2002): 365-395.

Floeren, Roberto Hans. "Crown Princes in the Clay. An Empirical Study on the Tackling of Succession Challenges in Dutch Family Farms." Assen : Van Gorcum Ltd.: 2002.

Gavard-Perret, Marie-Laure, David Gotteland, Christophe Haon and Alain Jolibert. Méthodologie de la recherche, Paris: Pearson Education France, 2008.

Gersick, Kelin E, John A. Davis, Marion McCollom Hampton and Ivan Lansberg. "Generation to Generation: Lifecycles of the Family Business," Boston: Harvard Business School Press, 1997.

Glaser Barney B and Anselm Strauss L. La découverte de la théorie ancrée. Stratégies pour la recherche qualitative. Paris: Armand Colin, 2010.

Girin, Jacques. «L'opportunisme méthodique dans les recherches sur la gestion des organisations. » Papier présenté à la journée d'étude La recherche-action en action et en question, AFCET, Collège de systémique, Ecole Centrale de Paris, France, 10 mars, 1989. 
Granovetter, Mark S. «Economic Action and Social Structure: the Problem of Embeddedness. » American Journal of Sociology, 91, (3) (1985): 481-510.

Habbershon, Timothy G, and Mary L. Williams. "A Resource-Based Framework for Assessing the Strategic Advantages of Family Firms.” Family Business Review 12 (1) (1999): 1-25.

Hall, DouglasT. and Down E. Chandler. "Psychological Success. When the Career is Talking.”Journal of Organizational Behaviour 26 (2005): 155-176.

Ibrahim, Bakr, Jean McGuire, and Khaled Soufani. "An Empirical Investigation of Factors Contributing to Longevity of Small Family Firms.” Global Economy \& Finance Journal 2, (2) (2009): 1-21.

Hirigoyen, Gérard. «Biais comportementaux dans l'entreprise familiale : antécédents et impacts. » Revue Economie et Sociétés, Série Economie de l'entreprise 10 (19) (2007a): 1901-1930.

Hirigoyen, Gérard. «La succession dans l'entreprise familiale : Une approche de gouvernance comportementale. » In, Mélanges en l'honneur de Pierre Spiteri, ed. Toulouse : Presses Universitaires de Toulouse, 2007 b.

Kenyon-Rouvinez, Denise, and John L. Ward (2004). Les entreprises familiales. Paris: Puf, Que sais-je?, 2004.

Kepner, Elaine. «The Family and the Firm: A Coevolutionary Perspective. » Organizational Dynamics 12, (1) (1983): 57-70.

Lansberg, Ivan. "Managing Human Resources in Family Firms: the Problem of Institutional Overlap.” Organizational Dynamics 12 (1983): 39-46.

Lansberg, Ivan, “The succession Conspiracy.” Family Business Review 1, (2) (1988): $119-143$.

Lubinski, Christina. "Succession In Multi-Generational Family Firms. An Explorative Study Into The Period Of Anticipatory Socialization.” Electronic Journal of Family Business Studies (EJFBS) 5 (1-2) (2011): 4-25.

Lumpkin, Tom G. and Keith H. Brigham. "Long-Term Orientation and Inter-temporal Choice in Family Firms." Entrepreneurship Theory and Practice November 35 issue 6 (2011): $1149-1169$

Mahmoud-Jouini, Sihem Ben, Alain Bloch and Sophie Mignon. "Capacités d'innovation des entreprises familiales pérennes. » Revue Française de Gestion 1, (200) (2010): 111-126. 
Meadows, Donella H., and Dennis L. Meadows and Jorgen Randers and W William W.

Behrens III. The Limits to Growth. A report for the club of Rome's Project on the

Predicament of Mankind. Washington: Potomac Associates, 1972.

Mebratu, Desta. «Sustainability and Sustainable Development: Historical and Conceptual Review. » Environmental Impact Assessment Review 18, (6) (1998): 493520 .

Miles, Matthew B. and Huberman, Michael A. Analyse des données qualitatives. Traduction de la $2^{\mathrm{e}}$ version américaine, Bruxelles: De Boeck, $2^{\mathrm{e}}$ édition, 2003.

Miller, Danny, and Isabelle Le Breton-Miller. Managing for the Long Run: Lesson in Competitive Advantage from Great Family Businesses. Boston: Harvard Business School Press, 2005.

Miller, Danny, and Isabelle Le Breton-Miller. «Family Governance and Firm Performance: Agency, Stewardship and Capabilities. » Family Business Review 19, (1) (2006): 73-87.

Miller, Danny, and Isabelle Le Breton-Miller. Réussir dans la durée -Leçons sur l'avantage concurrentiel des grandes entreprises familiales. Laval: Presse Universitaire Laval, 2011.

Mignon, Sophie. «Une approche de la pérennité de l'entreprise.» Thèse de Doctorat d'Université, Université de Nice-Sophia Antipolis, 1998.

Mignon, Sophie. «La pérennité des entreprises familiales : un modèle alternatif à la création de valeur pour l'actionnaire ?» Finance Contrôle Stratégie 3, (1) (2000): 169196.

Mignon, Sophie. «La pérennité organisationnelle, Un cadre d'analyse. », Revue Française de Gestion 2 (2009):73-89.

Minichiello, Victor, Rosalie Aroni, Eric Timewell and Loris Alexander. In-depth interviewing: Researching people. South Melbourne: Longman Cheshire, 1990. Mitcham, Carl. «The concept of sustainable development: its origins and ambivalence.» Technology in Society 17, (3) (1995): 311-326.

Olson, Patricia D., Virginia S. Zuiker, Sharon M. Danes, Kathryn Stafford, Ramona K.Z. Heck, and Karen A. Duncan. "The impact of the Family and the business on family business sustainability.” Journal of Business Venturing 18 (2003): 639-666.

Olson, David D. “Circumplex Model VII : Validation Studies and FACES III.” Family Process 25, (3) (1986): 337-351. 
O’Riordan, Timothy. “The New Environmentalisme and Sustainable Development." The Science of the Total Environment 108 (1991): 5-15.

Passet, René. L'Economique et le vivant, Paris: Economica $2^{\mathrm{e}}$ édition, 1996.

Pierce, Jon L, Tatiana Kostova, and Kurt T. Dirks. "Towards a Theory of Psychological Ownership in Organizations." Academy of Management Review 26 (2001): 298-310. Robic, Paulette. « La notion d'encastrement pour mieux comprendre le management stratégique des ruptures environnementales Le cas d'une entreprise laitière familiale. » Gestion 2000 4, juillet-août (2007): 47-60.

Robic, Paulette. «Le rôle des veuves-entrepreneures dans les entreprises familiales. » papier présenté à la Conférence de l'AIMS, Grenoble, France, juin 2-5, 2009.

Stafford, Kathryn, Karen A. Duncan, Sharon Dane and Mary Winter. "A research Model of Sustainable Family Businesses.” Family Business Review 12 (1999):197-208. World Commission on Environment and Development, Our Common Future, Oxford University Press, 1987.

${ }^{\mathrm{i}}$ Corresponding author : Nicolas Antheaume, nicolas.antheaume@ univ-nantes.fr

ii January 6, 2012. Interdisciplinary Seminar on Sustainable Development. Food supply and sustainable development, University of Nantes, France.

iii J. Venn, On the Diagrammatic and Mechanical Representation of Propositions and Reasonings, Philosophical Magazine and Journal of Science, Series 5, vol. 10, No. 59, July 1880.

${ }^{\text {iv }}$ www2.logement.gouv.fr/histo/default.htm (historical pages of the French Ministry of Housing, last consulted, January 2012). 